\title{
Clean Salt Process Final Report
}

\author{
D. L. Herting
}

Date Published

September 1996

Prepared for the U.S. Department of Energy

Assistant Secretary for Environmental Management

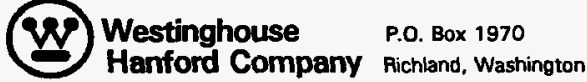

Management and Operations Contractor for the

U.S. Department of Eneroy under Contract DE-AC06-87RL10930

Approved for public release; distribution is unlimited 


\section{RELEASE AUTHORIZATION}

Document Number: WHC-EP-0915

Document Title: Clean Salt Process Final Report

Release Date: $\quad 9 / 30 / 96$

This document was reviewed following the procedures described in WHC-CM-3-4 and is:

APPROVED FOR PUBLIC RELEASE

WHC Information Release Administration Specialist:

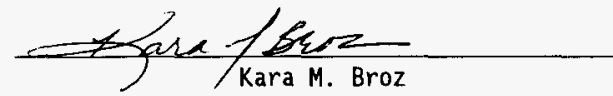

September 30, 1996 
WHC-EP-0915

\title{
CLEAN SALT PROCESS FINAL REPORT
}

\author{
D. L. Herting
}

\begin{abstract}
A process has been demonstrated in the laboratory for separating clean, virtually nonradioactive sodium nitrate from Hanford tank waste using fractional crystallization. The name of the process is the Clean Salt Process. Flowsheet modeling has shown that the process is capable of reducing the volume of vitrified low activity waste (LAW) by 80 to $90 \%$. Construction of the Clean Salt processing plant would cost less than $\$ 110$ million, and would eliminate the need for building a $\$ 2.2$ billion large scale vitrification plant planned for Privatization Phase II. Disposal costs for the vitrified LAW would also be reduced by an estimated $\$ 240$ million. This report provides a summary of five years of laboratory and engineering development activities, beginning in fiscal year 1992. Topics covered include laboratory testing of a variety of processing options; proof-of-principle demonstrations with actual waste samples from Hanford tanks 241-U-110 (U-110), 241-SY-101 (101-SY), and 241-AN-102 (102-AN); descriptions of the primary solubility phase diagrams that govern the process; a review of environmental regulations governing disposition of the reclaimed salt and an assessment of the potential beneficial uses of the reclaimed salt; preliminary plant design and construction cost estimates. A detailed description is given for the large scale laboratory demonstration of the process using waste from tank 241-AW-101 (101-AW), a candidate waste for vitrification during Phase I Privatization.
\end{abstract}

iii 
WHC-EP-0915

This page intentionally left blank. 
WHC-EP-0915

CONTENTS

1.0 INTRODUCTION $\ldots \ldots \ldots \ldots \ldots \ldots \ldots \ldots \ldots \ldots \ldots \ldots \ldots \ldots \ldots \ldots \ldots$

2.0 DEVELOPMENT HISTORY $\ldots \ldots \ldots \ldots \ldots \ldots \ldots \ldots \ldots \ldots \ldots \ldots .2-1$

2.1 FY 1992 - CONCEPT DEVELOPMENT, PROCESS

PARAMETERS AND TANK $110-\mathrm{U} \ldots \ldots \ldots \ldots \ldots \ldots \ldots \ldots . \ldots .1$

2.2 FY 1993 - TANK 101-SY, SINGLE SHELL TANK WASTE, AND MULTIPLE BATCH DEMONSTRATION $\ldots \ldots \ldots \ldots \ldots .2-4$

2.2.1 Tank 101-SY Simulated and Actual Waste Testing . . . . . . . 2-4

2.2.2 Single-Shell Tank Waste Flowsheet . . . . . . . . . . . 2-7

2.2.3 Multiple Batch Demonstration $\ldots \ldots \ldots \ldots \ldots \ldots$. . . . . . . .

2.3 FY 1994 - CRYSTALLIZATION PARAMETERS

AND ENGINEERING DEVELOPMENT . . . . . . . . . . . 2-11

2.3.1 Crystallization Parameters and Occlusion Studies . . . . . . . 2-11

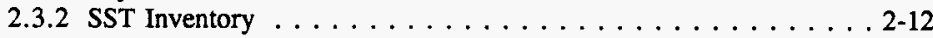

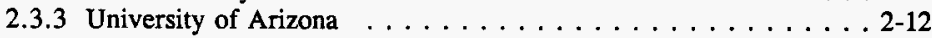

2.3.4 Engineering Flowsheet . . . . . . . . . . . . . 2-14

2.4 FY 1995 - TANK 102-AN, REGULATORY ANALYSIS $\ldots \ldots \ldots \ldots$ 2-14

2.4.1 Tank 102-AN . . . . . . . . . . . . . . 2-14

2.4 .2 Regulatory Analysis . . . . . . . . . 2-16

3.0 FISCAL YEAR $1996 \ldots \ldots \ldots \ldots \ldots \ldots \ldots \ldots \ldots \ldots \ldots \ldots$. $\ldots \ldots \ldots$

3.1 PROCESS FLOWSHEET FOR SPECIFIC WASTE TYPE $\ldots \ldots \ldots \ldots 3-1$

3.2 SOLUBILITY PHASE DIAGRAMS $\ldots \ldots \ldots \ldots \ldots \ldots \ldots \ldots \ldots$ 3-2

3.3 COST/BENEFIT ANALYSIS $\ldots \ldots \ldots \ldots \ldots \ldots \ldots \ldots \ldots \ldots$. $\ldots \ldots \ldots$

3.4 PRELIMINARY PLANT DESIGN/COST ESTIMATE $\ldots \ldots \ldots \ldots \ldots$ 3-3

3.5 CLEAN SALT PROCESS IN RUSSIA $\ldots \ldots \ldots \ldots \ldots \ldots \ldots$

4.0 LARGE SCALE DEMONSTRATION TEST WITH TANK 101-AW WASTE . . . . 4-1

4.1 SAMPLE PEDIGREE $\ldots \ldots \ldots \ldots \ldots \ldots \ldots \ldots \ldots \ldots \ldots$. $\ldots \ldots \ldots$

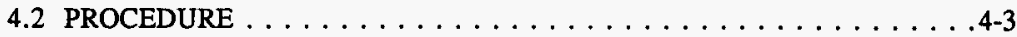

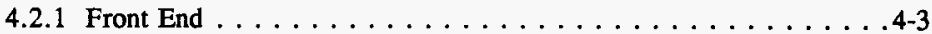

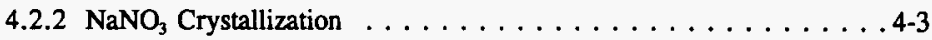

4.2.3 Combined FWR Solutions . . . . . . . . . . . 4-6

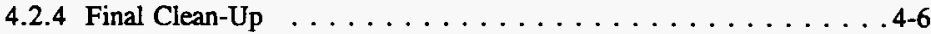

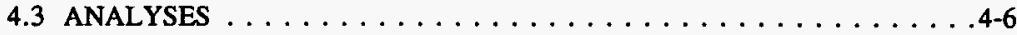

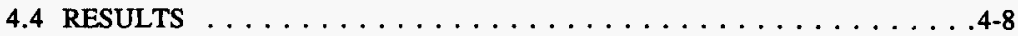

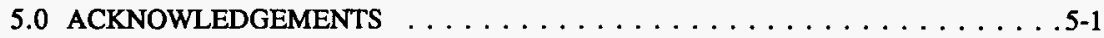

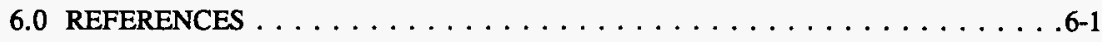


WHC-EP-0915

CONTENTS (Continued)

\section{APPENDIX}

A SOLUBILITY PHASE DIAGRAMS FOR THE SYSTEMS $\mathrm{NaNO}_{3} / \mathrm{Al}\left(\mathrm{NO}_{3}\right)_{3} / \mathrm{H}_{2} \mathrm{O}$

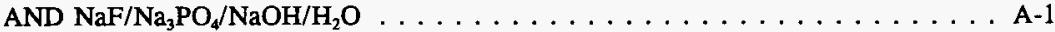

\section{LIST OF FIGURES}

2-1 Conceptual Mass Balance Flowsheet for Clean Salt Process Applied to SST Low-Activity Waste (LAW) . . . . . . . . . . . . . . . . 2-8

2-2 Occlusion Test Results. . . . . . . . . . . . . . . 2-13

4-1 Diagram Showing Recycling of Filtrate/Wash/Rinse Solutions

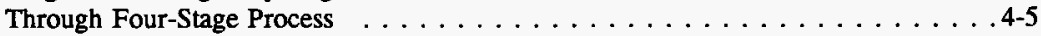

\section{LIST OF TABLES}

2-1 Composition" of Simulated and Actual Tank 110-U Sludge $\ldots \ldots \ldots \ldots \ldots$ 2-2

2-2 Composition of Simulated Double Shell Slurry Waste $\ldots \ldots \ldots \ldots \ldots$ 2-5

2-3 Mass Calculations for Water Wash of Tank 101-SY Composite Sample . . . . . 2-6

2-4 Composition of Tank 101-SY Acid Feed and Final Waste Streams . . . . . . . 2-7

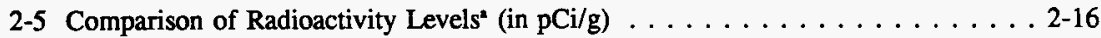

4-1 Analytical Results $(\mu \mathrm{g} / \mathrm{mL})$ for $2: 1$ Diluted Tank 101-AW Samples $\ldots \ldots \ldots \ldots$ 4-2

4-2 Analytical Sample Locations $\ldots \ldots \ldots \ldots \ldots \ldots \ldots \ldots . . \ldots \ldots$. . . . . . . . .

4-3 Analytical Results $\left(\mu \mathrm{g} / \mathrm{mL}\right.$ except $\mathrm{M}$ for $\mathrm{H}^{+}, \mu \mathrm{Ci} / \mathrm{mL}$ for $\left.{ }^{137} \mathrm{Cs}\right) \ldots \ldots \ldots$ 4-7

4-4 Comparison of Salt-Depleted LAW and Untreated LAW from Tank 101-AW (based on total inventory in six core segment samples) $\ldots \ldots \ldots \ldots \ldots . . \ldots 4$ 


\section{LIST OF TERMS}

$\begin{array}{ll}\text { DF } & \text { decontamination factor } \\ \text { ESP } & \text { Efficient Separations and Processing } \\ \text { FWR } & \text { filtrate/wash/rinse } \\ \text { FY } & \text { fiscal year } \\ \text { GEA } & \text { gamma energy analysis } \\ \text { HLW } & \text { high level waste } \\ \text { IPC/RAS } & \text { Institute of Physical Chemistry/Russian Academy of Science } \\ \text { LAW } & \text { low activity waste } \\ \text { RCRA } & \text { Resource Conservation and Recovery Act } \\ \text { RGS } & \text { retained gas sampling } \\ \text { SST } & \text { single-shell tank } \\ \text { TWRS } & \text { Tank Waste Remediation System }\end{array}$

vii 
This page intentionally left blank. 
WHC-EP-0915

\section{CLEAN SALT PROCESS FINAL REPORT}

\subsection{INTRODUCTION}

"Clean Salt Process" is the name coined to describe a radically different approach to pretreatment of Hanford radioactive waste stored in underground tanks. The process recovers virtually nonradioactive ("clean") sodium nitrate from the waste by fractional crystallization.

Traditionally, radioactive waste pretreatment efforts have been aimed at removing radionuclides from the waste by a variety of treatment methods. Fractional crystallization is the conceptually inverse process; that is, the nonradioactive salts are removed from the bulk waste, leaving the radionuclides behind.

The baseline treatment plan for waste from Hanford underground storage tanks is separation into high level waste (HLW), consisting of washed solids containing the bulk of the longlived isotopes, and low activity waste (LAW), consisting of the tank supernatant liquids and the liquids from sludge washing operations. Cesium (and possibly other radioelements) is removed from the LAW stream by ion exchange and combined with the HLW stream. The LAW stream is then immobilized by a to-be-named process with performance criteria equivalent to vitrification. The Clean Salt Process does not address the HLW stream, which is low in sodium. It deals only with the LAW stream, either before or after cesium ion exchange, where sodium salts account for over $90 \%$ by weight of the non-water components of the waste stream.

The process description is very simple. The LAW stream is acidified with nitric acid to $\mathrm{pH}$ 2. The acid solution is filtered to remove traces of insoluble solids, which are routed to the HLW. The clarified solution is evaporated until $\mathrm{NaNO}_{3}$ crystals form. The $\mathrm{NaNO}_{3}$ slurry is filtered. The filtrate, which contains the radionuclides, becomes the new saltdepleted LAW stream. The $\mathrm{NaNO}_{3}$ solids are washed with water or clean $\mathrm{NaNO}_{3}$ solution to remove contaminated interstitial liquid. The wash liquid is recycled to the evaporator, and the washed solids are recrystallized from water as often as required (two to four times, depending on contamination level in the LAW and on process parameters) to reach the desired level of decontamination.

This report closes out the activities performed under Technical Task Plan Number RL4-6-C3-41, "Selective Crystallization of Tank Supernatant Liquid." There will be no costs charged to this program after September 30, 1996. There are no outstanding environmental, safety, or other related issues remaining with this EM-50 funded activity. 
WHC-EP-0915

This page intentionally left blank. 
WHC-EP-0915

\subsection{DEVELOPMENT HISTORY}

Process development activities were initiated in fiscal year (FY) 1992 under a grant from the Westinghouse Hanford Company Development Steering Board. The grant was renewed for fiscal year 1993. During the following three years, funding was provided by the U.S. Department of Energy, Efficient Separations and Processing (ESP) Crosscutting Program.

\subsection{FY 1992 - CONCEPT DEVELOPMENT, PROCESS PARAMETERS AND TANK 110-U}

In April, 1992, the Westinghouse Hanford Company Development Steering Board awarded a \$75K seed money grant to develop the Clean Salt Process. The effort that year focused on performing a proof-of-principle test of the process on an actual tank waste. The only candidate waste sample available in the laboratory at that time was a sludge sample from tank U-110. Therefore, initial process development studies were based on a simulated waste representing that sludge sample. The chemical compositions of the actual and simulated sludges are shown in Table 2-1

Sludge washing tests were done on the simulated sludge to evaluate the effects of wash solution $\mathrm{pH}$ (water vs. $0.01 \mathrm{M} \mathrm{NaOH}$ ), wash solution to sludge weight ratio (1:1 vs. $2: 1$ ), and single wash at $2: 1$ ratio vs. two or three successive washes at $1: 1$ ratio. Based on analyses of the supematant liquid resulting from each of the wash scenarios, a single 1:1 water wash was chosen as the optimal condition providing the maximum dissolution of sodium nitrate with minimal dilution. No difference was observed between water and $0.01 \mathrm{M} \mathrm{NaOH}$ as the wash solution.

Sodium nitrate crystals were recovered from the 1:1 water wash solution by evaporation of the solution under a number of conditions. Parameters tested included pH (alkaline, neutral, acid) and addition of $\mathrm{Ca}\left(\mathrm{NO}_{3}\right)_{2}$ to remove competing anions as precipitates. Calcium addition was rejected because the solids that were produced were very fine and difficult to separate from the mother liquor.

Acidification to $\mathrm{pH} 2$ was selected over neutral or alkaline evaporation for a number of reasons. Alkaline solutions tend to be much more viscous than acidic solutions, leading to less efficient solid/liquid separation when the $\mathrm{NaNO}_{3}$ crystallizes. Crystallization under alkaline or neutral conditions leads to a mixture of $\mathrm{NaNO}_{3}, \mathrm{NaNO}_{2}$, and $\mathrm{Na}_{2} \mathrm{CO}_{3}$ crystals (and perhaps other sodium salts). The mixed crystals tend to have irregular (dendritic and acicular) habits, compared to the cube-like rhombohedral crystals of $\mathrm{NaNO}_{3}$ obtained under 
Table 2-1. Composition* of Simulated and Actual Tank 110-U Sludge.

\begin{tabular}{|c|c|c|c|c|}
\hline \multirow{2}{*}{ 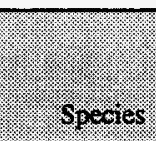 } & \multicolumn{2}{|c|}{ Weight $\%$} & \multirow[b]{2}{*}{ Comportid } & \multirow{2}{*}{$\begin{array}{l}\text { Weight } \\
\text { Simulated }\end{array}$} \\
\hline & $\begin{array}{l}\text { Areval } \\
\text { Surdge }\end{array}$ & $\begin{array}{l}\text { Sinulated } \\
\text { sliugge }\end{array}$ & & \\
\hline $\mathrm{Na}$ & 9.0 & 9.0 & $\mathrm{NaNO}_{3}$ & 8.50 \\
\hline $\mathrm{Al}$ & 9.0 & 9.0 & $\mathrm{Al}(\mathrm{OH})_{3}$ & 23.39 \\
\hline $\mathrm{Fe}$ & 1.0 & 1.0 & $\mathrm{Fe}_{2} \mathrm{O}_{3}$ & 2.74 \\
\hline $\mathrm{Bi}$ & 1.9 & 1.9 & $\mathrm{BiPO}_{4}$ & 1.44 \\
\hline$F^{-}$ & 0.7 & 0.7 & $\mathrm{NaAl}(\mathrm{OH})_{4}$ & 4.13 \\
\hline $\mathrm{NO}_{3}^{-}$ & 4.5 & 6.2 & $\mathrm{Na}_{3} \mathrm{PO}_{4} \bullet 12 \mathrm{H}_{2} \mathrm{O}$ & 9.50 \\
\hline $\mathrm{NO}_{2}^{-}$ & 0.9 & 0.9 & $\mathrm{NaF}$ & 1.55 \\
\hline $\mathrm{PO}_{4}{ }^{3-}$ & 3.2 & 3.2 & $\mathrm{NaNO}_{2}$ & 1.38 \\
\hline $\mathrm{SO}_{4}{ }^{2-}$ & 0.8 & 0.8 & $\mathrm{Na}_{2} \mathrm{SO}_{4}$ & 1.14 \\
\hline $\mathrm{CO}_{3}^{2-}$ & 0.4 & 0.4 & $\mathrm{Na}_{2} \mathrm{CO}_{3}$ & 0.74 \\
\hline TOC & 0.1 & 0.1 & $\mathrm{Na}_{2} \mathrm{C}_{2} \mathrm{O}_{4}$ & 0.13 \\
\hline $\mathrm{Si}$ & 4.1 & 4.1 & $\mathrm{Na}_{3}$ Citrate $\cdot 2 \mathrm{H}_{2} \mathrm{O}$ & 0.29 \\
\hline $\mathrm{H}_{2} \mathrm{O}$ & 34.8 & 40.0 & $\mathrm{Na}_{2} \mathrm{SiO}_{3} \bullet 9 \mathrm{H}_{2} \mathrm{O}$ & 11.93 \\
\hline $\mathrm{M}-\mathrm{OH}^{\mathrm{b}}$ & 22.3 & 22.5 & $\mathrm{SiO}_{2}$ & 6.19 \\
\hline $\mathrm{C}-\mathrm{OH}^{\mathrm{b}}$ & 0.2 & 0.2 & $\mathrm{NaOH}$ & 0.20 \\
\hline & & & $\mathrm{H}_{2} \mathrm{O}$ & 26.75 \\
\hline Total & 92.9 & 100.0 & Total & 100.00 \\
\hline
\end{tabular}

\section{Notes:}

"Composition of actual sludge by weight percent of element/anion, weight percent of simulated sludge by element/anion, and weight percent of simulated sludge by chemical compound.

"M-OH represents the weight of $\mathrm{O}$ and $\mathrm{H}$ associated with the metals $\mathrm{Al}, \mathrm{Fe}$ and $\mathrm{Si}$; $\mathrm{C}-\mathrm{OH}$ represents the weight of $\mathrm{O}$ and $\mathrm{H}$ associated with oxalate and citrate. 
WHC-EP-0915

acid conditions. Acidification of the wash solution converts $\mathrm{NaOH}, \mathrm{NaNO}_{2}$ and $\mathrm{Na}_{2} \mathrm{CO}_{3}$ to $\mathrm{NaNO}_{3}$ according to the reactions:

$$
\begin{aligned}
& \mathrm{NaOH}+\mathrm{HNO}_{3}--\longrightarrow \mathrm{NaNO}_{3}+\mathrm{H}_{2} \mathrm{O} \\
& 3 \mathrm{NaNO}_{2}+2 \mathrm{HNO}_{3}-\longrightarrow \longrightarrow 3 \mathrm{NaNO}_{3}+2 \mathrm{NO}+\mathrm{H}_{2} \mathrm{O} \\
& \mathrm{Na}_{2} \mathrm{CO}_{3}+2 \mathrm{HNO}_{3} \longrightarrow-\longrightarrow 2 \mathrm{NaNO}_{3}+\mathrm{CO}_{2}+\mathrm{H}_{2} \mathrm{O}
\end{aligned}
$$

Therefore, under acid conditions, most of the sodium in the water wash is recoverable as $\mathrm{NaNO}_{3}$.

After the overall process was demonstrated on simulated sludge samples, it was applied to a proof-of-principle test with the actual sludge. Tank 110-U was not the ideal tank to use for demonstrating the process, but it was the only tank for which sufficient sample was available to perform the test. Tank $110-\mathrm{U}$ is, in a sense, a more difficult case than a more typical single-shell tank (SST) because it is unusually low in sodium nitrate content. It contains only $6.2 \% \mathrm{NaNO}_{3}$ by weight, compared to the overall average of $25 \%$ for SST sludges, and $80 \%$ for SST salt cakes.

Tank 110-U sludge $(127 \mathrm{~g})$ was washed with water $(128 \mathrm{~g})$ at $50{ }^{\circ} \mathrm{C}$ for two hours. The diluted sludge was centrifuged, and the supernatant liquid was allowed to cool to room temperature. Large octahedral crystals formed upon cooling. The crystals, recovered by filtering, weighed $6.0 \mathrm{~g}$, and were identified by $\mathrm{x}$-ray diffraction and polarized light microscopy as sodium fluoride diphosphate hydrate, $\mathrm{Na}_{7} \mathrm{~F}\left(\mathrm{PO}_{4}\right)_{2} \bullet 19 \mathrm{H}_{2} \mathrm{O}$.

The filtrate solution was acidified to $\mathrm{pH} 2.5$ by slowly adding $6 \mathrm{M} \mathrm{HNO}_{3}$ to the filtrate. After centrifuging, the sample contained $3.5 \mathrm{~g}$ of solids and $91.9 \mathrm{~g}$ of pale blue green supernatant liquid. Slow evaporation of the liquid at $50{ }^{\circ} \mathrm{C}$ yielded $3.7 \mathrm{~g}$ of $\mathrm{NaNO}_{3}$ crystals, which were recrystallized once from water, recovering $1.9 \mathrm{~g}$ of recrystallized $\mathrm{NaNO}_{3}$. Gamma energy analysis (GEA) of the product for ${ }^{137} \mathrm{Cs}$ activity showed that a decontamination factor (DF) of 2000 had been achieved, where DF is defined as the ${ }^{137} \mathrm{Cs}$ activity per gram of tank 110 -U sludge sample divided by the ${ }^{137} \mathrm{Cs}$ activity per gram of $\mathrm{NaNO}_{3}$ product.

Details of the laboratory work on simulated and actual sludge samples were initially reported as an internal memo. The report was approved for public release as an appendix to a supporting document (Herting 1994). 


\subsection{FY 1993 - TANK 101-SY, SINGLE SHELL TANK WASTE, AND MULTIPLE BATCH DEMONSTRATION}

Due to the promising results obtained from the tank 110-U sample in FY 1992, the Development Steering Board seed money grant was extended for a second year at $\$ 85 \mathrm{~K}$. The main objective was to recover a sample of "virtually nonradioactive" $\mathrm{NaNO}_{3}$ from a tank waste, i.e., to recover a sample of $\mathrm{NaNO}_{3}$ that was sufficiently low in residual activity to qualify for unconditional release from the radiation zone (222-S Laboratory). At the time, the condition that had to be met to qualify for unconditional release was the sample had to be less than $200 \mathrm{pCi} / \mathrm{g}$ in total beta/gamma activity and less than $50 \mathrm{pCi} / \mathrm{g}$ in total alpha activity.

The goal was met twice during the year in process demonstrations with a core composite sample from tank 101-SY. The $\mathrm{NaNO}_{3}$ samples had total activities (mainly ${ }^{137} \mathrm{Cs}$ ) of 58 and $25 \mathrm{pCi} / \mathrm{g}$. Decontamination factors for ${ }^{137} \mathrm{Cs}$ were 10 million and 14 million, respectively. No activity could be detected in the recovered salt samples with a standard Geiger-Müller counter. Neither one of the samples would cause the alarm to sound when the sample was placed in a hand-and-foot counter.

These experiments proved that the Clean Salt Process is technically feasible. A detailed report of these experiments, complete with mass flow diagrams, was issued as a supporting document (Herting 1993). A brief summary is included here (Section 2.2.1).

The other effort during FY 1993 was to produce a mass flowsheet for treatment of SST LAW, and to test the flowsheet with a simulated waste in a multiple batch treatment, approximating continuous plant operation. These efforts are described in Sections 2.2.2 and 2.2.3.

\subsubsection{Tank 101-SY Simulated and Actual Waste Testing}

Double shell slurry waste, exemplified by tank 101-SY waste, is not the ideal candidate for clean salt processing, mainly because of the large amount of acid required to neutralize the carbonate and aluminate ions in solution. A series of tests were done with a simulated waste (Table 2-2) to evaluate various methods of treating the waste.

Laboratory tests showed that removal of $\mathrm{Na}_{2} \mathrm{CO}_{3}$ was possible by heating the solution to near boiling. (The solubility of $\mathrm{Na}_{2} \mathrm{CO}_{3}$ is reduced by elevating the temperature.) The anhydrous $\mathrm{Na}_{2} \mathrm{CO}_{3}$ is easily recrystallized from water to produce large well-formed crystals of $\mathrm{Na}_{2} \mathrm{CO}_{3} \bullet 10 \mathrm{H}_{2} \mathrm{O}$. However, due to the added processing steps required, this method was not used for the actual waste tests done later. 
Table 2-2. Composition of Simulated Double Shell Slurry Waste.

\begin{tabular}{|c|c|}
\hline Component & Concentration, W : \\
\hline $\mathrm{NaOH}$ & 2.0 \\
\hline $\mathrm{NaAl}(\mathrm{OH})_{4}$ & 1.5 \\
\hline $\mathrm{NaNO}_{3}$ & 2.6 \\
\hline $\mathrm{NaNO}_{2}$ & 2.2 \\
\hline $\mathrm{Na}_{2} \mathrm{CO}_{3}$ & 0.42 \\
\hline $\mathrm{Na}_{3} \mathrm{HEDTA}^{*}$ & 0.20 \\
\hline Density, g/mL & 1.36 \\
\hline
\end{tabular}

Note:

'HEDTA = N-(2-hydroxyethyl)ethylenediaminetriacetate

An attempt was made to drastically reduce the acid requirement by doing a caustic-side precipitation of $\mathrm{NaNO}_{3}$ and $\mathrm{NaNO}_{2}$ by evaporation (after removing $\mathrm{Na}_{2} \mathrm{CO}_{3}$ ), then dissolving the recovered salts in water, acidifying the solution, and proceeding as usual. This scheme was abandoned for two reasons. Product recovery was low, and the supernatant liquid remaining from the $\mathrm{NaNO}_{3} / \mathrm{NaNO}_{2}$ precipitation had the undesirable quality that it would turn to a paste due to the slow formation of $\mathrm{Al}(\mathrm{OH})_{3}$. Precipitation of $\mathrm{Al}(\mathrm{OH})_{3}$ occurred because its solubility is dramatically affected by the ionic strength of the solution -- as the ionic strength is reduced by precipitating the sodium salts, the solubility of aluminum falls sharply. The kinetically slow $\mathrm{Al}(\mathrm{OH})_{3}$ precipitation could lead to serious process upsets such as plugging of transfer pipes.

Two actual waste demonstrations were done on a whole-tank core composite sample containing a mixture of convective and non-convective core segments from the Window $\mathrm{C}$ and Window $\mathrm{E}$ sampling events. In the first test, the slurry was washed with water $(120 \mathrm{~g}$ slurry and $120 \mathrm{~g}$ water) for 22 hours at $60 \circ \mathrm{C}$ to dissolve the sodium salts. The slurry was centrifuged, yielding $196 \mathrm{~g}$ of water wash solution and $20 \mathrm{~g}$ of centrifuged solids. The water wash solution, representing the LAW stream, was used for the $\mathrm{NaNO}_{3}$ recovery, and the solids were discarded.

The water wash solution was analyzed to determine the starting composition for mass flow calculations (Table 2-3), and to determine how much nitric acid would be required to acidify the solution. The acidification was performed by adding $109 \mathrm{~g}$ of $12 \mathrm{M} \mathrm{HNO}_{3}$ to a $400 \mathrm{~mL}$ beaker, then slowly adding $168 \mathrm{~g}$ of the water wash solution. A trace of solids remained in the acidified solution, and they were removed by filtration. 
WHC-EP-0915

The clear filtrate was evaporated, and three crops of $\mathrm{NaNO}_{3}$ crystals were recovered, weighing a total of $75 \mathrm{~g}$. The product sait was recrystallized three times from water, with a final yield of $4 \mathrm{~g}$ of $\mathrm{NaNO}_{3}$ with a total activity of $58 \mathrm{pCi} / \mathrm{g}$ and a ${ }^{137} \mathrm{Cs}$ activity of $51 \mathrm{pCi} / \mathrm{g}$. Losses were due to (1) sampling of the product at each stage, (2) inevitable losses due to the solubility of $\mathrm{NaNO}_{3}$-- some salt remains in solution when the product crystals are removed by filtration, and (3) normal attrition due to laboratory methods. In an actual operating plant, nearly all of the $75 \mathrm{~g}$ of product would be retained by recycling filtrate and wash streams.

The procedure for the second test was the same as for the first test. The final product yield was $16 \mathrm{~g}$ of $\mathrm{NaNO}_{3}$ with $25 \mathrm{pCi} / \mathrm{g}$ total activity. Detailed mass flow calculations presented in Herting (1993) and summarized in Table 2-4 show that the sodium content of the LAW stream was reduced by $80 \%$.

Table 2-3. Mass Calculations for Water Wash of Tank 101-SY Composite Sample.

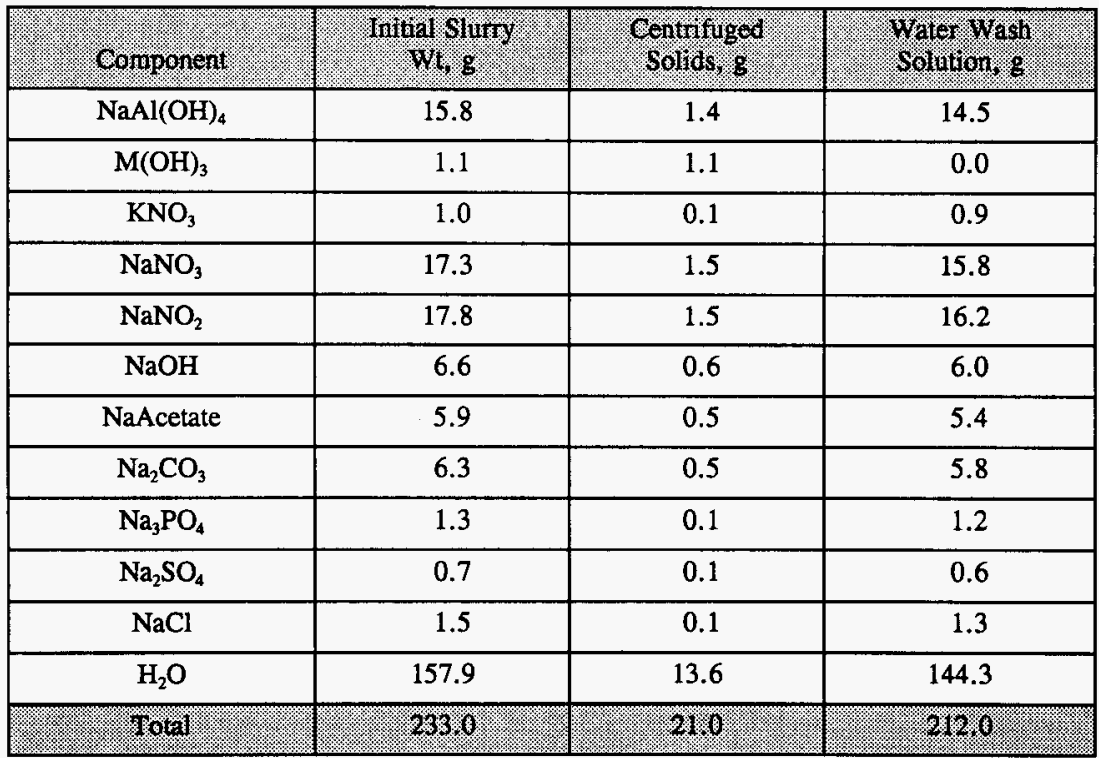


Table 2-4. Composition of Tank 101-SY Acid Feed and Final Waste Streams.

\begin{tabular}{|c|c|c|c|}
\hline Bormporicit & $\begin{array}{l}\text { Actinged } \\
\text { Solunon, } 8\end{array}$ & produgl & $\begin{array}{l}\text { Final Waste } \\
\text { Strean, } 8 \text {. }\end{array}$ \\
\hline $\mathrm{NaNO}_{3}$ & 76.5 & 61.4 & 15.0 \\
\hline $\mathrm{Al}\left(\mathrm{NO}_{3}\right)_{3}$ & 26.1 & & 26.1 \\
\hline $\mathrm{CH}_{3} \mathrm{COOH}$ & 4.0 & & 4.0 \\
\hline $\mathrm{KNO}_{3}$ & 0.9 & & 0.9 \\
\hline $\mathrm{HNO}_{3}$ & 7.1 & & 7.1 \\
\hline $\mathrm{H}_{3} \mathrm{PO}_{4}$ & 0.7 & & 0.7 \\
\hline $\mathrm{H}_{2} \mathrm{SO}_{4}$ & 0.4 & & 0.4 \\
\hline $\mathrm{NaCl}$ & 1.3 & & 1.3 \\
\hline $\mathrm{H}_{2} \mathrm{O}$ & 195.8 & & 36.0 \\
\hline Tont. & 312.7 & . 61.4 & 91.5 \\
\hline
\end{tabular}

\subsubsection{Single-Shell Tank Waste Flowsheet}

At this point in the development of the Clean Salt Process, it was desirable to calculate a mass balance flowsheet that would provide a basis for evaluation of the process as a waste pretreatment method. The flowsheet was specific to solutions arising from sludge washing in the SST farms. This LAW stream represents by far the largest single type of LAW planned for pretreatment. It is much more amenable to Clean Salt Processing than double shell slurry because of its relatively high concentration of $\mathrm{NaNO}_{3}$. The composition of the feed solution was derived from the estimated average overall SST sludge wash solution composition given in Stordeur (1986), Boomer and Baker (1991).

The mass balance flowsheet is shown in Figure 2-1. The solid rectangle in the figure represents the conceptual boundaries of the Clean Salt Process. Everything that appears outside the box is either an input to or an effluent from the process. 


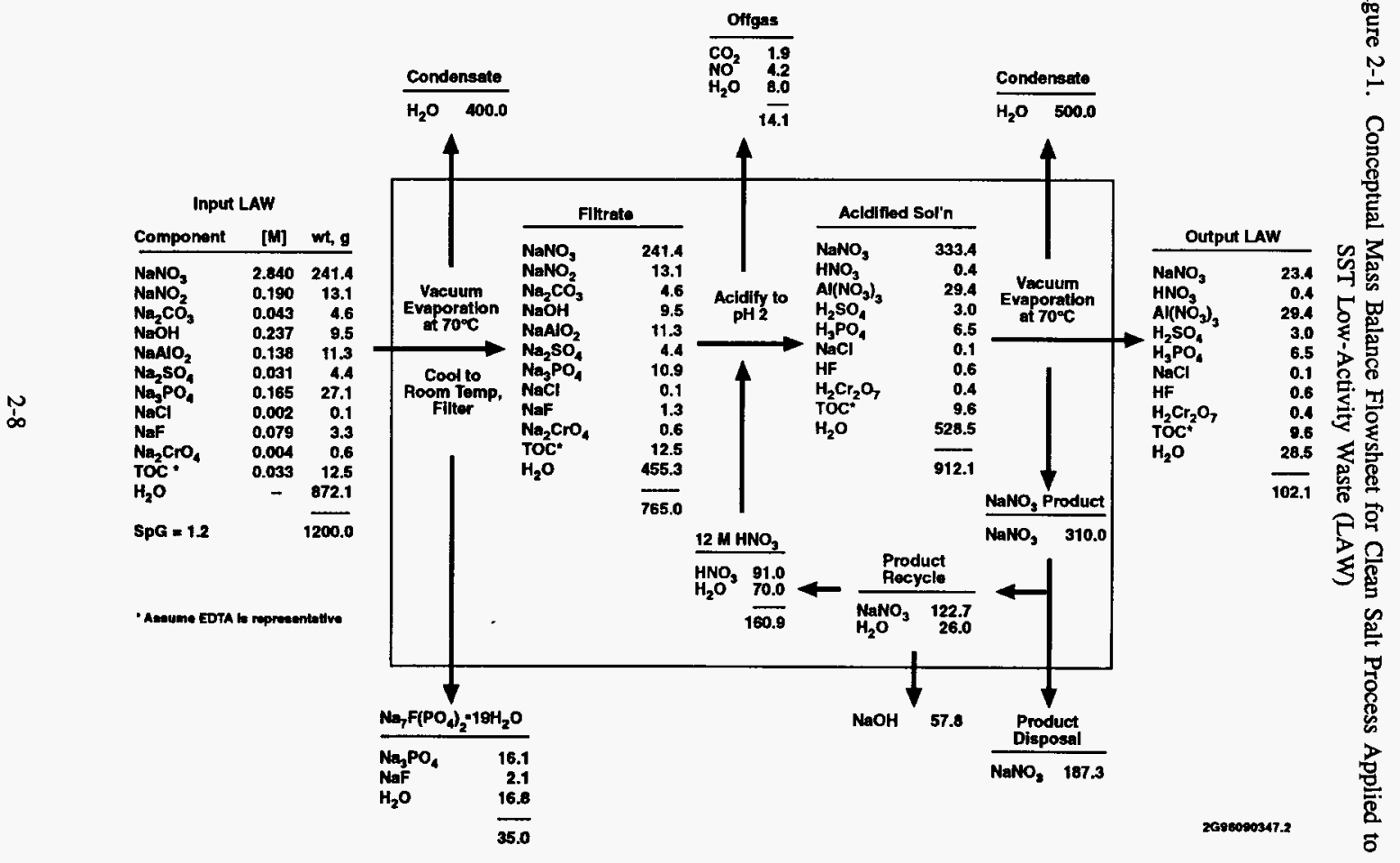


Step 1 - Evaporation: Concentrations of most or all of the major salts in the sludge wash solution are well below solubility limits. The first step of the Clean Salt Process calls for reducing the volume of the solution by vacuum evaporation. This step could be accomplished in the present 242-A vacuum evaporator/crystallizer. The condensate could be recycled without treatment for use in sludge washing.

One alternative that has been proposed is to remove the aluminum from solution before evaporation. That would be accomplished by bubbling $\mathrm{CO}_{2}$ gas through the solution to precipitate dawsonite, $\mathrm{NaAlCO}_{3}(\mathrm{OH})_{2}$. Aluminum removal would have the beneficial effect of reducing the acid demand in the later acidification step of the process, but there are obvious drawbacks. Bubbling $\mathrm{CO}_{2}$ gas through the aluminate solution can produce either dawsonite, which forms large, filterable crystals, or it can produce gelatinous $\mathrm{Al}(\mathrm{OH})_{3}$. The conditions that favor one solid over another are proprietary secrets, according to telephone conversations with Aluminum Company of America personnel.

Step 2 - Cool to Room Temperature: Cooling the concentrated solution to room temperature would cause precipitation of the double salt $\mathrm{Na}_{7} \mathrm{~F}\left(\mathrm{PO}_{4}\right)_{2} \bullet 19 \mathrm{H}_{2} \mathrm{O}$. At the time the flowsheet was developed, this salt was considered as a possible product that could be decontaminated to virtually nonradioactive levels. Recent tests (see Appendix A) show that the double salt cannot be decontaminated from ${ }^{90} \mathrm{Sr}$, and probably other isotopes, by simple recrystallization.

It is desirable to remove the double salt from the waste stream because fluoride and phosphate both have detrimental effects in the vitrification process. However, a viable processing option is to leave the salt in solution by simply not cooling the solution. The fluoride and phosphate would then wind up in the final treated LAW stream. The hydrofluoric acid would probably not add to corrosion problems as long as there is sufficient aluminum in solution to complex the fluoride.

Step 3 - Acidification: In the proposed flowsheet, the source of the nitric acid is the $\mathrm{NaNO}_{3}$ recovered in the process. The product salt could be converted to nitric acid and sodium hydroxide by thermal or electrochemical methods. Less than half of the product $\mathrm{NaNO}_{3}$ is needed to supply the $\mathrm{HNO}_{3}$ used in the acidification.

Step 4 - Evaporation: Evaporation of the acidified solution to precipitate $\mathrm{NaNO}_{3}$ would require a new facility designed specifically for precipitation and recrystallization (the details of which are not included in the mass balance flowsheet). There are significant parallels between this step of the process and the commercial recovery of $\mathrm{NaNO}_{3}$ from its ore, as practiced in Chile. Therefore, the proposed process is not without considerable commercial experience on which to draw. The preliminary plant design was worked out in FY 1996.

The aluminum nitrate remaining in solution (if it is not removed at the beginning of the process) acts as a salting out agent to help reduce the solubility of the $\mathrm{NaNO}_{3}$. It can also co-precipitate with the $\mathrm{NaNO}_{3}$ when the mother liquor becomes concentrated in aluminum. 
The contamination of the $\mathrm{NaNO}_{3}$ with aluminum could be a large problem or no problem, depending on the disposition of the product salt. The solubility phase diagram for the $\mathrm{NaNO}_{3} / \mathrm{Al}\left(\mathrm{NO}_{3}\right)_{3} / \mathrm{HNO}_{3} / \mathrm{H}_{2} \mathrm{O}$ system was reported in FY 1996. (See Appendix A.)

Step 5 - Product Recycle: The recrystallized $\mathrm{NaNO}_{3}$ can be handled in a non-shielded facility for conversion of the salt into nitric acid and sodium hydroxide by thermal or electrochemical treatment. Nitric acid cannot be produced in this way as cheaply as it could be purchased commercially, but when the cost savings of not having to store or dispose of the product $\mathrm{NaNO}_{3}$ is considered, an overall savings would be accrued.

Step 6 - Final Waste Treatment: Treatment/disposal of the final waste stream falls outside the boundaries of the Clean Salt Process, but is not unaffected by the process. Because the $\mathrm{Na}$ : Cs ratio is reduced by one order of magnitude, the enhanced efficiency of the cesium ion exchange process leads to a substantial cost savings (documented in FY 1995).

A proposal was also considered to recover aluminum from the final waste stream as a potential "clean salt" by precipitation of ammonium alum, $\mathrm{NH}_{4} \mathrm{Al}\left(\mathrm{SO}_{4}\right)_{2} \bullet 12 \mathrm{H}_{2} \mathrm{O}$. Laboratory testing with simulated waste was done to evaluate the proposal. Very large octahedral crystals of ammonium alum were obtained. By thermally decomposing the crystals, the ammonium sulfate reagent needed to form the crystals can be recovered for recycle. The aluminum is converted to alumina, $\mathrm{Al}_{2} \mathrm{O}_{3}$. This process has been carried out on a pilot plant scale for commercial recovery of alumina from clay (Deleplaine and McCullough 1955, Peters et al. 19 ).

\subsubsection{Multiple Batch Demonstration}

The flowsheet described in the previous section was tested in the laboratory by performing a multiple batch treatment of a simulated SST sludge wash solution. A one liter $(1200 \mathrm{~g})$ sample of the simulated waste having the composition shown in Figure 2-1 was divided into ten batches of equal size. Each batch was treated according to the flowsheet, and the product $\mathrm{NaNO}_{3}$ from each batch was recrystallized three times from water.

Each sequential solid/liquid separation is referred to as a "stage". The initial separation of $\mathrm{NaNO}_{3}$ crystals from the acidified LAW is Stage 1. The first recrystallization of the product $\mathrm{NaNO}_{3}$ is Stage 2, etc. In each batch, the filtrate from Stage 1 was combined to form the final salt-depleted LAW. Filtrates from Stages 2-4 were recycled to the feed for the prior stage of the following batch. Each filtered $\mathrm{NaNO}_{3}$ product was washed with water, and the wash liquid was recycled to the same stage in the following batch.

One procedural difficulty was encountered during the test. With each succeeding stage, recrystallization of the product $\mathrm{NaNO}_{3}$ became more difficult because the crystals developed a water-insoluble contaminant that tended to plug filters. The contaminant is believed to have come from the plastic disposable filter units that were used. When solutions were 
recycled through a number of these filter units, they apparently leached the contaminant out of either the filter membranes or the plastic bodies of the filter units.

Extensive records were maintained during the 10-batch test to keep track of the mass flow through the system. The data are recorded in controlled laboratory notebook RHO-RE-NB-252, pages 61-151, and WHC-N-313-4, pages 37-46. Results of the test confirmed the feasibility of the flowsheet calculations in Figure 2-1. Lessons learned and techniques developed during the test were utilized in the large scale process demonstration on tank 101-AW waste performed three years later.

\subsection{FY 1994 - CRYSTALLIZATION PARAMETERS AND ENGINEERING DEVELOPMENT}

Funding for FY 1994 studies was provided by a $\$ 300 \mathrm{~K}$ grant from the Office of Technology Development, within the U.S. Department of Energy's Office of Environmental Management, under the ESP Integrated Program (name later changed to ESP Crosscutting Program). The technical effort was directed along four fronts - laboratory studies of $\mathrm{NaNO}_{3}$ crystallization parameters, surrogate waste compositions, contracting for university research, and engineering flowsheet development and modeling. A supporting document was issued (Herting and Lunsford 1994) to describe the work that was done during the fiscal year. A brief summary is included in the following sections.

\subsubsection{Crystallization Parameters and Occlusion Studies}

In the laboratory, experiments with simulated waste were done to explore the effects of crystallization parameters on the size and crystal habit of product $\mathrm{NaNO}_{3}$ crystals.

Crystallization temperature and cooling temperature had little or no effect on crystal size or habit. Crystal size ranged from 50 to 190 micrometers. The only factor that did affect crystal size was whether the solution was stirred during the crystallization. In the unstirred samples, the crystals grew to be quite large, as much as $7 \mathrm{~mm}$ in diameter.

Other experiments with simulated waste were done to test the solid/liquid separation efficiency. Decontamination of the product salt depends directly on the separation efficiency because virtually all of the radionuclides are in the liquid phase.

Even with perfect solid/liquid separation, the decontamination of the salt is not perfect because of crystal defects called occlusions. Clusters of contaminants are trapped in pockets (occlusions) within the rapidly growing crystals, or where two or more crystals grow together. This contamination cannot be washed away with the liquid phase. 
Two independent tests were done with impure (radioactively contaminated) $\mathrm{NaNO}_{3}$ recovered from tank 101-SY. In each test, the crystals were dissolved in water, then analyzed to determine total ${ }^{137} \mathrm{Cs}$ content. The solution was evaporated to recrystallize the $\mathrm{NaNO}_{3}$, which was then washed four times with a saturated $\mathrm{NaNO}_{3}$ solution. The recrystallization filtrate and all wash solutions were analyzed for ${ }^{137} \mathrm{Cs}$ activity. The washed crystals were then dissolved in water and analyzed. Analytical results were used to calculate the percentage of the initial ${ }^{137} \mathrm{Cs}$ activity that remained in the crystals after each step. A graph of the results is shown in Figure 2-2.

The residual activity drops after each wash step because the wash liquid displaces the interstitial liquid trapped in the crystal bed by capillary forces. It reaches an asymptotic level which cannot be lowered any more by washing, because the residual activity is trapped in occlusions inside the crystals. In both tests, the amount of ${ }^{137} \mathrm{Cs}$ trapped in occlusions was $0.14 \%$ of the amount present in the initial sample. This implies that the achievable decontamination factor cannot be higher than $100 / 0.14=700$. In actuality, the DF is limited by incomplete solid/liquid separation, not by occlusions, to a range of approximately 50 to 100 for each process stage. The overall $\mathrm{DF}$ for a multi-stage process is $\mathrm{DF}^{\mathrm{n}}$, where $\mathrm{n}$ is the number of stages. If $\mathrm{DF}=75$ for a 3 -stage process, the overall DF would be $75^{3}=$ $4 \times 10^{5}$.

A detailed report of the crystal growth and occlusion studies was issued as a supporting document (Herting 1994).

\subsubsection{SST Inventory}

In preparation for defining surrogate waste compositions, SSTs were categorized according to the weight percent $\mathrm{NaNO}_{3}$ in each tank. A report was issued as an appendix to Herting and Lunsford (1994). Analysis of the tank inventory data indicated that approximately $80 \%$ by weight of the waste in SST's is amenable to pretreatment by the Clean Salt Process. The other $20 \%$ of the waste contains too little $\mathrm{NaNO}_{3}$ to warrant processing, or contains enough soluble sodium aluminate to make processing difficult.

\subsubsection{University of Arizona}

A contract with the University of Arizona went into effect on May 1, 1994, to build a benchscale continuous crystallizer using simulated Hanford waste. The principal investigator there was Dr. Alan Randolph. He is a world-class crystallization expert, and has expertise in Hanford waste chemistry through past consulting contracts. He was instrumental in the selection of the design of Hanford's 242-A and 242-S evaporator/crystallizers that have been used since the mid-1970's to reduce the volume of tank waste. 
Figure 2-2. Occlusion Test Results.

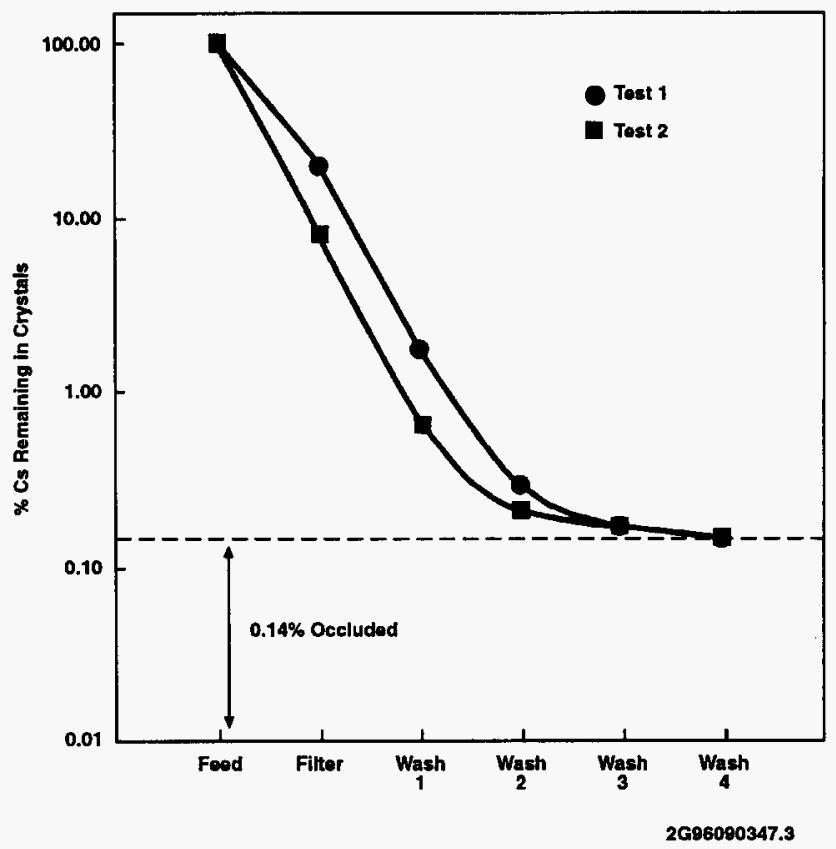


Dr. Randolph endorsed the concept of the Clean Salt Process. He and his staff built a bench scale mixed-suspension-mixed-product-removal continuous crystallizer, and used it to perform some preliminary measurements of crystal nucleation rates, crystal growth rates, and slurry handling characteristics. Unfortunately, the funding for the contract was cut by the Department of Energy in late 1994 due to budget cutbacks (see Section 2.4).

\subsubsection{Engineering Flowsheet}

A detailed process flowsheet and computer model were created using the ASPENPlus steady state process simulator. This is the same program being used by the Tank Waste Remediation System (TWRS) program for their waste pretreatment and disposal projections. Therefore, evaluations can be made of the effect of the Clean Salt Process on the LAW volume and composition resulting from the TWRS baseline flowsheet. A detailed description of the engineering flowsheet was published in a supporting document (Lunsford 1994).

\subsection{FY 1995 - TANK 102-AN, REGULATORY ANALYSIS}

Funding for FY 1995 studies was provided by a \$500K grant from the Department of Energy's ESP Crosscutting Program. Due to ESP Crosscutting Program funding cutbacks early in the fiscal year (December 1994), the project funding was cut to $\$ 50 \mathrm{~K}$, and a number of planned activities were canceled, including the contract with the University of Arizona. Partial funding was re-instated in pieces as the fiscal year progressed, to a final total of $\$ 217 \mathrm{~K}$ for the fiscal year. The re-instated funding allowed for completion of two projects. Laboratory work on a process demonstration with complexed concentrate waste from tank 102-AN was allowed to go to completion. A contract with IT Corporation (which employed $\mathrm{CH} 2 \mathrm{M}$ Hill as a subcontractor) to survey the environmental regulations governing disposition options for the recovered clean salt was also completed.

\subsubsection{Tank 102-AN}

A bottle-on-a-string supernatant liquid sample labeled 102-AN-1 was taken from tank 102AN on October 21, 1994. The sample was centrifuged to remove a trace of suspended solids, and the liquid from the centrifuge cones was used for a Clean Salt Process demonstration. The laboratory procedure for the Clean Salt Process demonstration test is recorded in controlled laboratory notebook WHC-N-384-2, pages 64-89.

Tank 102-AN is a complexed concentrate waste containing approximately $26 \mathrm{~g}$ total organic carbon (TOC) per liter. During earlier process development testing with simulated waste from tank 101-SY, it had been noted that an organic destruction reaction took place during the evaporative concentration of the acidified solution. The Clean Salt Process flowsheet was 
WHC-EP-0915

adjusted for the 102-AN sample to increase the acid concentration in the acidified feed to enhance the organic destruction reaction. The target acid concentration was changed to $1 \mathbf{M}$ nitric acid.

Twelve molar $\mathrm{HNO}_{3}(128 \mathrm{~g})$ was placed in a $400 \mathrm{~mL}$ beaker, and $140 \mathrm{~g}$ of the tank $102-\mathrm{AN}$ supernatant liquid was added. The acidified solution was filtered to remove a trace of solids. The filtrate was evaporated at approximately 80 to $110 \circ \mathrm{C}$ until $\mathrm{NaNO}_{3}$ formed. Gas evolution, indicative of the organic destruction reaction taking place and liberating carbon dioxide, was taking place the whole time. The rate of gas evolution seemed to increase dramatically when crystals were present. As the gas evolution rate increased, the temperature would climb by 10 to $20 \circ \mathrm{C}$, causing the crystals to dissolve. then the gas evolution rate would slow down, the temperature would fall, the $\mathrm{NaNO}_{3}$ crystals would form again, and the process would cycle over. Small amounts of water were added to maintain a constant volume while this cycling reaction took place for approximately 5 hours. The gas evolution was still taking place at a steady pace when the heat was turned off and the solution allowed to cool.

After the solution had cooled, it was filtered to remove $33 \mathrm{~g}$ of $\mathrm{NaNO}_{3}$ crystals. Approximately one-third of the filtrate was lost in a spill. The remaining filtrate was evaporated further to recover a second crop of $\mathrm{NaNO}_{3}(15 \mathrm{~g})$ and a third crop $(3 \mathrm{~g})$. Analysis of the final filtrate showed that approximately $40 \%$ of the TOC had been destroyed during the heating. Presumably, the percentage of TOC decomposed could have been improved by optimizing the reaction conditions.

All of the crystals were washed with saturated $\mathrm{NaNO}_{3}$ solutions, and the filtrates were discarded. The washed crystals were recrystallized four times from water, with a final recovery of $5.5 \mathrm{~g}$ of pure $\mathrm{NaNO}_{3}$ crystals that were analyzed for total activity. The crystals received unconditional release from the laboratory when the total activity was found to be $4 \mathrm{pCi} / \mathrm{g}$ (see Table 2-5).

Decontamination factors were measured for six radioisotopes across the first stage crystallization. The DF's were defined as the activity of the isotope per gram of centrifuged liquid tank waste divided by the activity of the same isotope per gram of Stage $1 \mathrm{NaNO}_{3}$

crystals. The measured DF's were essentially the same for all six isotopes: ${ }^{137} \mathrm{Cs}-51,{ }^{60} \mathrm{Co}$ $-48,{ }^{154} \mathrm{Eu}-50,{ }^{90} \mathrm{Sr}-42,{ }^{241} \mathrm{Am}-55,{ }^{99} \mathrm{Tc}-46$. These results indicate that the same decontamination mechanism is operating for all of the isotopes. 
WHC-EP-0915

Table 2-5. Comparison of Radioactivity Levels' (in pCi/g).

\begin{tabular}{|c|c|}
\hline Tand I02-AN Siperuatant I Iquid & $4 \times 10^{3}$ \\
\hline Fertilizer ("triple 16") & 100 \\
\hline Granite & 40 \\
\hline Meadow grass & 25 \\
\hline Soil (U.S. Average) & 15 \\
\hline $\mathrm{NaNO}_{3}$ from Tank 102-AN & 4 \\
\hline Human Body & 2 \\
\hline
\end{tabular}

Note:

"See NCRP Report No. 45.

\subsubsection{Regulatory Analysis}

A contract was placed with IT Corporation to perform an assessment of the federal, state and local environmental laws that would govern various disposition options for the $\mathrm{NaNO}_{3}$ recovered by the Clean Salt Process. A supporting document (Herting 1995) was issued at the conclusion of the contract. The options covered in the document included:

- Recycle for use in onsite acid/caustic production process

- Recycle for use as onsite fertilizer

- Recycle for use in onsite ion exchange column backwash

- Onsite disposal in Inert Waste Disposal Facility

- Onsite disposal in Low Level Waste Disposal Facility

- Onsite disposal in Mixed Waste Disposal Facility

- Offsite disposal in Inert Waste Disposal Facility

- Offsite disposal in Resource Conservation and Recovery Act (RCRA) Waste Disposal Facility.

In general, regulations such as RCRA and the State of Washington Dangerous Waste Regulations encourage the identification of beneficial reuse options. There are very few regulatory constraints on the reuse of the $\mathrm{NaNO}_{3}$ salt. The primary constraint on reuse is the technical feasibility of the reuse options, which was not addressed in this document, but was addressed in a document issued in FY 1996 (Hendrickson 1996).

The regulatory analysis pointed out the need for development of offsite release criteria for material with radioactive contamination in depth or in volume. Currently, no release criteria have been established. During the following three years, funding was provided by the U.S. Department of Energy Office of Science and Technology (EM-50) Efficient Separations and Processing (ESP) Crosscutting Program. 
WHC-EP-0915

\subsection{FISCAL YEAR 1996}

Funding for FY 1996 studies was provided by a $\$ 250 \mathrm{~K}$ grant from the Department of Energy's ESP Crosscutting Program. Several chemistry and engineering tasks were accomplished. Each task is described in one of the following subsections, except the large scale demonstration test with actual waste, which is described in Section 4.0.

\subsection{PROCESS FLOWSHEET FOR SPECIFIC WASTE TYPE}

The first milestone task for FY 1996 was to issue a report describing a process flowsheet for pretreatment of a low activity waste stream from a specific feed tank. Tank 101-AW was selected so that the computer model flowsheet would be calculated for the same waste that was being used for the large scale process demonstration in the laboratory (see Section 4.0). A Westinghouse Hanford Company Internal Memo was issued, the conclusions of which are summarized here.

The same ASPENPlus steady state process simulator computer program was used for this flowsheet as for the engineering process flowsheet developed in FY 1994 (Section 2.3.4). Volumes of vitrified waste produced from tank 101-AW LAW were calculated under three sets of conditions: (1) TWRS Process Flowsheet with no Clean Salt Process, (2) Clean Salt Process added before the cesium ion exchange module in TWRS Process Flowsheet, and (3) Clean Salt Process added after the cesium ion exchange module.

The number of containers of vitrified LAW, each measuring $32 \mathrm{~m}^{3}$, was calculated for each set of conditions. For the baseline flowsheet (no Clean Salt Process), the tank 101-AW LAW would produce 92 containers. That number is reduced to 21 containers if the Clean Salt Process is added before cesium ion exchange and 22 containers if the Clean Salt Process is added after cesium ion exchange. With the "before" case, the number of elution/regeneration cycles for the cesium ion exchange process is reduced from 108 cycles (baseline) to 33 cycles, representing a substantial cost savings in ion exchange processing. (The cost trade-off, which has not been calculated, is that the Clean Salt Plant would be larger and more costly if the process were implemented before cesium ion exchange.)

There is a cautionary statement in the report that the vitrified LAW volume reduction could be limited by the activity of ${ }^{99} \mathrm{Tc}$ in the salt-depleted LAW stream. However, ${ }^{99} \mathrm{Tc}$ removal processes and waste loading limits for ${ }^{99} \mathrm{Tc}$ in the glass are still being debated. 
WHC-EP-0915

\subsection{SOLUBILITY PHASE DIAGRAMS}

Knowledge of chemical solubility is vital in being able to predict mass flows for the Clean Salt Process. The system $\mathrm{NaF} / \mathrm{Na}_{3} \mathrm{PO}_{4} / \mathrm{NaOH} / \mathrm{H}_{2} \mathrm{O}$ governs the precipitation of the double salt sodium fluoride diphosphate, $\mathrm{Na}_{7} \mathrm{~F}\left(\mathrm{PO}_{4}\right)_{2} \bullet 19 \mathrm{H}_{2} \mathrm{O}$, and establishes the concentrations of fluoride and phosphate in the treated LAW stream. The system $\mathrm{NaNO}_{3} / \mathrm{Al}\left(\mathrm{NO}_{3}\right)_{3} / \mathrm{HNO}_{3} / \mathrm{H}_{2} \mathrm{O}$ governs the separation of sodium and aluminum in the clean salt product, and also affects the degree of $\mathrm{NaNO}_{3}$ recovery possible because the solubility of $\mathrm{NaNO}_{3}$ is substantially lowered by the salting-out effect of $\mathrm{Al}\left(\mathrm{NO}_{3}\right)_{3}$.

A Westinghouse Hanford Company Internal Memo was issued with the results of the phase diagram investigations. Because of the importance of the solubility data to the Clean Salt Process, the internal memo is attached as Appendix A.

\subsection{COST/BENEFIT ANALYSIS}

Each of the potential disposition options for clean $\mathrm{NaNO}_{3}$ recovered by the Clean Salt Process was subjected to an engineering evaluation and cost/benefit analysis. The results of these evaluations were published (Hendrickson 1996).

Two disposition options were considered viable. Both options offer a potential $\$ 2.2$ billion savings in Privatization Phase II large scale vitrification plant capital construction costs. One option was off-site release of the clean salt for industrial uses. This option offered a calculated savings of approximately $\$ 1$ billion in LAW disposal costs.

The second option was conversion of the $\mathrm{NaNO}_{3}$ to $\mathrm{Na}_{2} \mathrm{CO}_{3}$ by calcination. The $\mathrm{Na}_{2} \mathrm{CO}_{3}$ would be used as a ballast for back-filling the storage tanks after the wastes were removed. This option would save approximately $\$ 630$ million in LAW disposal costs. After the report was published, some concern was expressed by stakeholders that use of $\mathrm{Na}_{2} \mathrm{CO}_{3}$ as a back-fill material may not be advisable due to the potential for the carbonate to dissolve in the groundwater, cause leaching of radionuclides from the soil surrounding the tanks, and result in increased rates of transport of the radionuclides to the Columbia River. If the $\mathrm{Na}_{2} \mathrm{CO}_{3}$ is used as an amendment to a cementitious material that is used as the ballast, as recommended in Hendrickson (1996), then the radionuclide transport issue may be avoided.

Other potential clean salt disposition options were discounted for one of two reasons. Either the option was not tenable for technical reasons, or the option required too small a fraction of the recovered salt. Some of these options include:

- Use as an on-site fertilizer in surface barrier construction (revegetation): uses less than $1 \%$ of the recovered salt. 
- Use as ion exchange regenerant at on-site Treated Effluent Disposal Facility: not technically feasible; current process uses sulfuric acid for regeneration; use of nitrate would impact downstream ultraviolet oxidation process for organic destruction.

- Electrolytic or thermal conversion to $\mathrm{NaOH}$ and $\mathrm{HNO}_{3}$ : technically feasible, but TWRS programmatic needs for $\mathrm{NaOH}$ and $\mathrm{HNO}_{3}$ are projected at approximately $18 \%$ of the chemicals that would be produced from the recovered $\mathrm{NaNO}_{3}$, leaving the remaining $82 \%$ still in need of disposal.

- On-site disposal of $\mathrm{NaNO}_{3}$ : more costly than vitrification as LAW.

\subsection{PRELIMINARY PLANT DESIGN/COST ESTIMATE}

Estimates of cost savings accrued by reducing the volume of the LAW stream are useless unless some estimate can be made of how much it would cost to build and operate the Clean Salt Plant. These estimates are being made by an engineering study whose report (MacLean 1996) is being written concurrently with this one. The construction cost estimate for the plant is $\$ 106$ million, and would eliminate the need for the $\$ 2.2$ billion large scale vitrification plant planned for Privatization Phase II.

\subsection{CLEAN SALT PROCESS IN RUSSIA}

On August 30, 1995, Mr. Calvin Delegard gave a seminar on Hanford tank waste origin and treatment to members of the Institute of Physical Chemistry/Russian Academy of Science (IPC/RAS) in Moscow, Russia. Mr. Delegard is the Hanford liaison with the IPC/RAS for studies on the chemistry of actinide elements and technetium in alkaline media. The report was not received in time to be included in this document. When the report is received, it will be edited and issued as a separate document in FY 1997.

As a result of follow-up inquiries, and through the efforts of the International Program Office of the DOE-ESP Crosscutting Program, a contract was placed with the IPC/RAS to do a literature search through the classified documents regarding their clean salt process applications, and to issue a report, suitable for public release, that summarizes the classified information. The report was received just as this document was going to press, and is attached as Appendix B in un-edited form. It will be edited and issued as a separate document in FY 1997. 
WHC-EP-0915

This page intentionally left blank. 
WHC-EP-0915

\subsection{LARGE SCALE DEMONSTRATION TEST WITH TANK 101-AW WASTE}

Three times in the past, samples of $\mathrm{NaNO}_{3}$ recovered from actual tank wastes received unconditional release from the 222-S laboratory. The largest of these samples weighed 16 grams. The purposes of the large scale demonstration test were (1) to show that improved recovery was possible by incorporating recycle streams into the process, and (2) to provide a quantity of recovered $\mathrm{NaNO}_{3}$ large enough to permit testing by other laboratories, if desired. Tank 101-AW was selected as the sample source because it is one of the feed tanks designated for Phase I Privatization, and because there was a sufficiently large amount of tank 101-AW waste available in the 222-S laboratory.

\subsection{SAMPLE PEDIGREE}

Two core samples, 22 segments each, were taken from tank 101-AW in February, 1996. Seven segments (identified below) were analyzed for entrapped gas content and composition with the retained gas sampling (RGS) equipment. The RGS testing does not alter the solid/liquid composition of the waste except that a 2:1 water:waste dilution is made to promote release of gas bubbles. The diluted wastes would normally have been discarded, but were used instead for the Clean Salt Process large scale demonstration. The first step in applying the Clean Salt Process to a tank waste sample is to dilute the waste with water to dissolve soluble sodium salts, so the RGS testing simply replaced the first step of the Clean Salt Process.

The following samples are identified throughout this report as Samples 1-7:

Sample 1 - diluted Segment 21 from Riser 24A

Sample 2 - diluted Segment 17 from Riser 24A

Sample 3 - diluted Segment 08 from Riser 24A

Sample 4 - diluted Segment 18 from Riser 24B

Sample 5 - diluted Segment 19 from Riser 24A

Sample 6 - diluted Segment 20 from Riser 24B

Sample 7 - diluted Segment 22 from Riser 24B

Each of the diluted samples was analyzed prior to being used for the large scale demonstration. Analytical results are shown in Table 4-1. 
WHC-EP-0915

Table 4-1. Analytical Results $(\mu \mathrm{g} / \mathrm{mL})$ for 2:1 Diluted Tank 101-AW Samples.

\begin{tabular}{|c|c|c|c|c|c|c|c|}
\hline Sample. & 1. & 2. & 3 & 4. & 15. & 6. & 7.7 \\
\hline $\mathrm{Al}$ & 8540 & 9370 & 10400 & 9520 & 9220 & 7420 & 9260 \\
\hline $\mathbf{K}$ & 12500 & 13200 & 13100 & 13700 & 13100 & 10700 & 13200 \\
\hline $\mathrm{Na}$ & 98400 & 95400 & 83500 & 95700 & 90600 & 81700 & 94100 \\
\hline $\mathbf{P}$ & 460 & 440 & 130 & 355 & 540 & 360 & 370 \\
\hline$S$ & 1080 & 1000 & 140 & 840 & 740 & 880 & 1030 \\
\hline$F$ & 2400 & 2050 & $<15$ & 1690 & 1780 & 2000 & 1890 \\
\hline $\mathrm{Cl}^{-}$ & 1810 & 1840 & 1840 & 1760 & 1900 & 1370 & 1530 \\
\hline $\mathrm{NO}_{2}^{-}$ & 30900 & 30300 & 27700 & 30300 & 31500 & 24100 & 26900 \\
\hline $\mathrm{NO}_{3}^{-}$ & 73600 & 63200 & 51700 & 69700 & 66100 & 54100 & 59300 \\
\hline $\mathrm{PO}_{4}{ }^{3-}$ & 970 & 890 & 250 & 650 & 1280 & 800 & 530 \\
\hline $\mathrm{SO}_{4}{ }^{2-}$ & 3100 & 2680 & 220 & 2260 & 2120 & 2500 & 2560 \\
\hline $\mathrm{C}_{2} \mathrm{O}_{4}^{2-}$ & 1040 & 980 & 250 & 1140 & 1110 & 1700 & 840 \\
\hline TIC" & 4940 & 4480 & 466 & 3730 & 3670 & 3850 & 4220 \\
\hline TOC & 4130 & 1790 & 1360 & 1780 & 1720 & 2280 & 1980 \\
\hline $\mathrm{OH}^{-}$ & 24700 & 26400 & 27800 & 20000 & 25900 & 17300 & 25800 \\
\hline $\mathrm{NH}_{3}$ & $\mathrm{na}^{\mathrm{b}}$ & 110 & 120 & 126 & 136 & $\mathrm{na}^{\mathrm{b}}$ & $\mathrm{na}^{\mathrm{b}}$ \\
\hline $\begin{array}{c}{ }^{137} \mathrm{Cs} \\
(\mu \mathrm{Ci} / \mathrm{mL})\end{array}$ & 125 & 134 & 137 & 135 & 132 & 98 & 130 \\
\hline $\begin{array}{l}\text { Density } \\
(\mathrm{g} / \mathrm{mL})\end{array}$ & 1.160 & 1.197 & 1.194 & 1.204 & 1.210 & 1.164 & 1.15 \\
\hline
\end{tabular}

Notes:

TIC $=$ total inorganic carbon; TOC $=$ total organic carbon

na = not analyzed 


\subsection{PROCEDURE}

Each diluted RGS sample was treated sequentially in the fashion described earlier for the simulated SST waste (Section 2.2.3), and described in more detail in the following sections. The procedures and data are recorded in controlled laboratory notebook WHC-N-384-4, pages 32-100.

\subsubsection{Front End}

The RGS activities were performed in the 1E-2 hotcell in the 222-S Laboratory. Each diluted sample was transferred in a 1-L plastic bottle to the 1E-1 hotcell to initiate the Clean Salt Process large scale demonstration. Dose rates for the diluted samples were estimated at approximately $10 \mathrm{rad} / \mathrm{hr}$ at contact.

The diluted RGS samples are analogous to the LAW stream in the TWRS baseline flowsheet where the LAW is being fed to the cesium ion exchange module, except that the diluted RGS samples contain undissolved solids that the LAW would not have. Sample volumes recovered from the RGS equipment ranged from 650 to $900 \mathrm{~mL}$ with approximately $50 \mathrm{~mL}$ per sample of settled solids. The first step in the large scale demonstration, then, was to separate the diluted liquid from the solids. This separation was done by decanting the liquid into a tared 1-L squirt bottle.

From the total weight of decanted liquid and the acid demand analysis, the weight of $12 \mathrm{M}$ $\mathrm{HNO}_{3}$ needed to acidify the liquid to $\mathrm{pH} 2$ was calculated. The required $\mathrm{HNO}_{3}$ was placed in a 2-L beaker with a large stirbar. The diluted waste was then added to the $\mathrm{HNO}_{3}$ by squeezing the squirt bottle. The total time required to complete the waste addition was typically 20 minutes.

The acidified waste was stirred for at least 24 hours. The waste invariably contained a small amount (estimated at less than one gram) of suspended solids, which were removed by filtering through a Büchner funnel with a filter paper. The filtrate was transferred to a clean 1-L beaker to begin the Stage 1 crystallization.

\subsection{2 $\mathrm{NaNO}_{3}$ Crystallization}

A four-stage $\mathrm{NaNO}_{3}$ recovery was planned according to the flowsheet shown in Figure 4-1. The following sections describe the crystallization procedure for a typical Sample N. 
4.2.2.1 Stage 1. For Sample $N$ (where $N=2$ through 7), the first step in Stage 1 of the process was to add the filtrate/wash/rinse (FWR) solution from Sample N-1 Stage 2 to the acid feed from the front end. The resulting solution (which was the original acid feed for Sample 1) was evaporated by heating on a hotplate/stirrer to approximately $80^{\circ} \mathrm{C}\left( \pm 20^{\circ} \mathrm{C}\right)$. As soon as crystals of $\mathrm{NaNO}_{3}$ were observed, the heat was tumed off.

When the slurry had cooled to room temperature, it contained approximately $50 \%$ settled solids. The slurry was vacuum-filtered using the same Büchner funnel as in the front end. The crystals were washed with water while still in the Büchner funnel. The washed crystals (Crop 1) were transferred to tared, labeled plastic jar.

The original filtrate and the water-wash filtrate were combined and transferred back to the 1-L beaker that held the slurry. The filter paper, funnel, and filter flask were then rinsed with water, and the rinse solution was also added to the beaker. The combined filtrate/water wash/rinse is referred to as the FWR solution. The evaporation step was repeated until a second crop of crystals was obtained, which was added to the first crop. The FWR solution was evaporated again to obtain a third crop of crystals. The final FWR solution was saved for combining with the FWR solutions from other samples for further concentration and additional $\mathrm{NaNO}_{3}$ recovery. (Note the simplification of Figure 4-1 at this point.)

4.2.2.2 Stage 2. The three crops of $\mathrm{NaNO}_{3}$ crystals from Stage 1 were dissolved in water, and the solution was filtered. The FWR solution from Sample N-1 Stage 3 was added, and the solution was evaporated until solids formed. Three crops of crystals were recovered and washed as described for Stage 1. The final FWR solution was saved for Sample N+1 Stage 1 . The crystals were sufficiently low in activity (typically $20 \mathrm{mrad} / \mathrm{hr}$ dose rate at contact) that they could be transferred from the $1 \mathrm{E}-1$ hotcell to a hood in room $1 \mathrm{D}$.

4.2.2.3 Stage 3. The three crops of $\mathrm{NaNO}_{3}$ crystals from Stage 2 were dissolved in water, and the solution was filtered through a plastic disposable filter unit. The FWR solution from Sample N-1 Stage 4 was added to the filtrate, and the solution was evaporated in an open beaker until solids formed. Three crops of crystals were recovered and washed as described for Stage 1. The final FWR solution was saved for Sample N+1 Stage 2. The crystals recovered in Stage 3 had typical dose rates of less than $1 \mathrm{mrad} / \mathrm{hr}$ and activities (Geiger/Müller counter) of approximately 1000 counts/min.

4.2.2.3 Stage 4. The three crops of $\mathrm{NaNO}_{3}$ crystals from Stage 3 were dissolved in water, and the solution was filtered through a plastic disposable filter unit. The solution was evaporated in an open beaker until solids formed. Three crops of crystals were recovered and washed as described for Stage 1. The final FWR solution was saved for Sample N+1 Stage 3. The crystals recovered in Stage 4 had activities that were barely detectable with a Geiger/Müller counter. 
Figure 4-1. Diagram Showing Recycling of Filtrate/Wash/Rinse Solutions Through Four-Stage Process

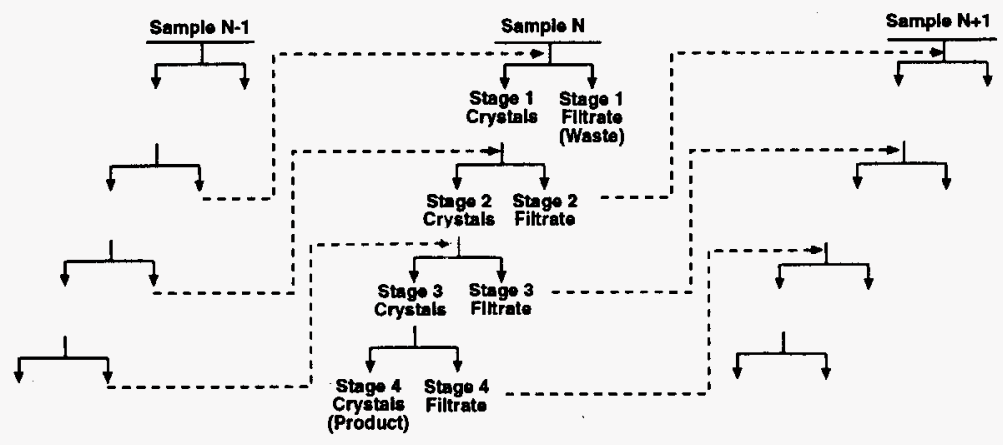

2009090347.1 


\subsubsection{Combined FWR Solutions}

The Stage 1 FWR solutions from Samples 1-5 and Sample 7 were further evaporated to recover addition $\mathrm{NaNO}_{3}$. (Sample 6 was lost along with the FWR solution from Sample 5 Stage 2 when the beaker broke during the evaporation process for Stage 1.) Six crops of crystals, containing some aluminum nitrate nonhydrate, potassium nitrate, and sodium sulfate in addition to sodium nitrate, were recovered in Stage 1. The final filtrate from Stage 1 Crop 6, representing the composition of the salt-depleted LAW stream, was analyzed.

The six crops of crystals were recrystallized as described above, with two exceptions: (1) Due to the increased concentration of ${ }^{137} \mathrm{Cs}$ in the feed solution, an extra separation stage was required. Stage 3 had to be done in the $1 \mathrm{E}-1$ hotcell, and Stages 4 and 5 were done in a hood in room 1D. (2) The FWR solutions were discarded instead of recycled. These solutions represent unavoidable product losses in a batch process. The potassium, aluminum, and sulfate components extracted in Stage 1 were lost in the FWR solutions that were discarded during the recrystallizations.

\subsubsection{Final Clean-Up}

The Stage 4 product $\mathrm{NaNO}_{3}$ crystals from Samples 1-5 and Sample 7 had a combined weight of 587 grams and a low, but detectable, count rate of approximately 50 counts/min (benchtop Geiger-Müller counter). The crystals were still too contaminated to qualify for unconditional release from the laboratory, so they were subjected to a Stage 5 recrystallization. Three crops of crystals weighing $\mathbf{4 1 8}$ grams were recovered. These crystals were analyzed by GEA, and were found to contain ${ }^{137} \mathrm{Cs}$ at $27 \mathrm{pCi} / \mathrm{g}$.

The Stage $5 \mathrm{NaNO}_{3}$ product from the combined FWR solutions weighed 394 grams, and had an activity similar to the Stage 4 product from the other samples. Time ran out (i.e., the fiscal year ended) before the product could be recrystallized one last time.

\subsection{ANALYSES}

To do a complete mass balance for the entire large scale demonstration test would have required analysis of the product and filtrate from every stage of every sample. The cost of the analyses would have far exceeded the budget. Therefore, representative samples were analyzed for key components at the points in the process indicated in Table 4-2. Analytical results are shown in Table 4-3. 
Table 4-2. Analytical Sample Locations.

\begin{tabular}{|c|c|c|}
\hline Customet & Iabeore & I \\
\hline HE384311 & S96R000530 & Sample 3 Stage 1 feed before recycle added \\
\hline HE384411 & S96R000514 & Sample 4 Stage 1 feed after recycle added \\
\hline HE384421 & S96R000515 & Sample 4 Stage 2 feed before recycle added \\
\hline HE384422 & S96R000516 & Sample 4 Stage 2 feed after recycle added \\
\hline HE384431 & S96R000539 & Sample 4 Stage 3 feed before recycle added \\
\hline HE384441 & S96R000540 & Sample 4 Stage 4 feed \\
\hline HE384811 & S96R000625 & FWR Stage 1 Final Filtrate (diluted with $\mathrm{H}_{2} \mathrm{O}, 1.8 \mathrm{~mL}$ to \\
& 15 mL total volume) \\
\hline HE384821 & S96R000626 & $\begin{array}{c}\text { FWR Stage 2 Feed before recycle } \\
\text { (dissolved Stage 1 product) }\end{array}$ \\
\hline
\end{tabular}

Table 4-3. Analytical Results $\left(\mu \mathrm{g} / \mathrm{mL}\right.$ except $\mathrm{M}$ for $\mathrm{H}^{+}, \mu \mathrm{Ci} / \mathrm{mL}$ for $\left.{ }^{137} \mathrm{Cs}\right)$.

\begin{tabular}{|c|c|c|c|c|c|c|c|c|}
\hline 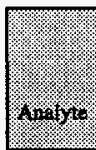 & 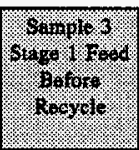 & 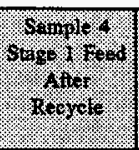 & 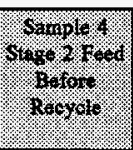 & 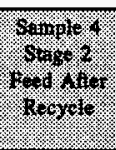 & 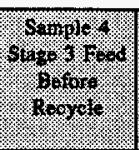 & 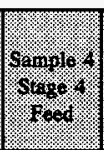 & 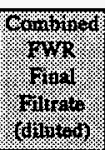 & 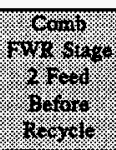 \\
\hline $\mathrm{H}^{+}$ & 0.30 & 0.47 & 0.008 & $<0.005$ & $n a^{b}$ & na & pH 3.5 & $n^{b}$ \\
\hline$\overline{\mathrm{Al}}$ & 6560 & 5850 & 300 & 210 & 120 & $<20$ & $\overline{6540}$ & 10100 \\
\hline $\mathbf{K}$ & 9180 & 8400 & 690 & 530 & 380 & $<200$ & 7720 & 17800 \\
\hline $\mathrm{Na}$ & 69600 & 67500 & 117000 & 114000 & 173000 & 168000 & 5340 & 137000 \\
\hline $\mathbf{P}$ & 375 & 170 & $<40$ & $<40$ & $<80$ & $<80$ & 226 & 321 \\
\hline $\mathbf{S}$ & 540 & 530 & 34 & 24 & $<40$ & $<40$ & 159 & 240 \\
\hline${ }^{137} \mathrm{Cs}$ & 96.1 & 91.8 & 4.5 & 3.1 & 1.6 & 0.03 & 93.1 & 118 \\
\hline $\mathrm{Na} / \mathrm{Cs}$ & $\overline{724}$ & 735 & 26000 & 36800 & 108000 & $\begin{array}{r}560000 \\
0\end{array}$ & 57 & 1160 \\
\hline $\mathrm{Al} / \mathrm{Cs}^{2}$ & 68 & 64 & 67 & 68 & 75 & -- & $\overline{70}$ & 86 \\
\hline $\mathrm{K} / \mathrm{Cs}^{\mathbf{2}}$ & $\overline{96}$ & 92 & 153 & 171 & 238 & -- & 83 & 151 \\
\hline
\end{tabular}

Notes:

\footnotetext{
'Ratios expressed as $\mu \mathrm{g}$ metal per $\mu \mathrm{Ci}{ }^{137} \mathrm{Cs}$

na $=$ not analyzed
} 
WHC-EP-0915

\subsection{RESULTS}

The Stage 5 product $\mathrm{NaNO}_{3}$ from Samples $1-5$ and Sample 7 had a final ${ }^{137} \mathrm{Cs}$ activity of $27 \mathrm{pCi} / \mathrm{g}$. No other radionuclides were detected by GEA.

Decontamination factors for each stage of recrystallization can be estimated from the $\mathrm{Na} / \mathrm{Cs}$ ratios in Table 4-3. Using the ratios determined before recycle streams are added to the feed for each stage, the DF's for Sample 4 were approximately 35, 4, and 50 for Stage 1/2, 2/3, and $3 / 4$, respectively. The Stage $2 / 3 \mathrm{DF}$ is probably hampered by the techniques required for handling the samples with remote manipulators in the $1 \mathrm{E}-1$ hotcell. It is very difficult to prevent contamination of the product salt when the manipulator fingers must be placed into the recrystallizing solution to lift a beaker, for example.

The overall DF for the process can be defined as the average ${ }^{137} \mathrm{Cs}$ activity in the feed $(108 \mu \mathrm{Ci} / \mathrm{g})$ divided by the ${ }^{137} \mathrm{Cs}$ activity in the recovered $\mathrm{NaNO}_{3}\left(2.7 \times 10^{-5} \mu \mathrm{Ci} / \mathrm{g}\right)$. The overall DF is thus approximately $4 \times 10^{6}$.

By comparing the analytical results of the feed samples with the analysis of the final FWR Stage 1 filtrate, an estimate can be made of the overall sodium recovery efficiency. By multiplying the concentration of each key analyte in the feed by the volume of each feed solution, the total feed inventory of each analyte can be calculated. This inventory can be compared to the amount found in the final filtrate (representing the salt-depleted LAW) by assuming that $100 \%$ of the ${ }^{137} \mathrm{Cs}$ reports to the final filtrate. The percentage of each analyte that reports to the salt-depleted LAW can then be found by ratio to the ${ }^{137} \mathrm{Cs}$. The results of these calculations are shown in Table 4-4.

Table 4-4. Comparison of Salt-Depleted LAW and Untreated LAW from Tank 101-AW (based on total inventory in six core segment samples).

\begin{tabular}{|c|c|c|c|c|}
\hline grativie & Units. & 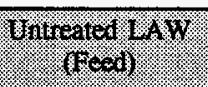 & $\begin{array}{l}\text { Salveppleted } \\
\text { low }\end{array}$ & 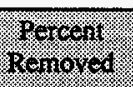 \\
\hline${ }^{137} \mathrm{Cs}$ & $\mathrm{Ci}$ & 0.59 & 0.59 & 0 \\
\hline $\mathrm{Na}$ & grams & $365.7^{a}$ & 33.7 & 91 \\
\hline $\mathbf{K}$ & grams & 58.3 & 48.7 & 17 \\
\hline Al & grams & 41.7 & 41.2 & 1 \\
\hline$S$ & grams & 3.6 & 1.0 & 72 \\
\hline
\end{tabular}

Note:

'Adjusted to account for recycled Na from Sample 5 lost in Sample 6 Stage 1. 
The clean salt product obtained from the six core samples in a continuous-operation plant with full recycle would have contained $1227 \mathrm{~g} \mathrm{NaNO}_{3}, 25 \mathrm{~g} \mathrm{KNO}_{3}, 12 \mathrm{~g} \mathrm{Na}_{2} \mathrm{SO}_{4}$, and $4 \mathrm{~g}$ $\mathrm{Al}\left(\mathrm{NO}_{3}\right)_{3}$. (These numbers are calculated by taking the difference between the feed and product : AW columns in Table 4-4, and multiplying the difference by the molecular weight of the compound divided by the atomic weight of the element.) The $\mathrm{KNO}_{3}, \mathrm{Na}_{2} \mathrm{SO}_{4}$, and $\mathrm{Al}\left(\mathrm{NO}_{3}\right)_{3}$ were not recovered 25 clean salts because they were discarded with the FWR solutions in the combined FWK recrystallizations.

The actual weight of clean $\mathrm{NaNO}_{3}$ recovered was $812 \mathrm{~g}$, the balance $(415 \mathrm{~g}$ ) having been discarded along with the combined FWR solutions. 
WHC-EP-0915

This page intentionally left blank. 


\subsection{ACKNOWLEDGEMENTS}

The author is deeply indebted to Wayne Edmonson for his dedication to the project, and his diligence in performing dozens of recrystallizations with remote manipulators in the 1E-1 hotcell. The large scale demonstration project could not have been completed without his skill and commitment.

The author is grateful for assistance from Jim Sloughter with the initial concept development and funding. Others who have contributed technical assistance to the project over its fiveyear duration include Todd Lunsford, Eric Slaathaug, Graham MacLean, Doug Hendrickson, and summer students Tim Mhyre and Mike Korenko. Cal Delegard provided valuable consultations, especially with the IPC/RAS.

This work was funded by a grant from the U.S. Department of Energy Office of Science and Technology (EM-50) Efficient Separations and Processing Crosscutting Program. 
WHC-EP-0915

This page intentionally left blank: 


\subsection{REFERENCES}

Boomer, K. D., and S. K. Baker, A. L. Boldt, M. D. Britton, L. E. Engelsman, J. D. Galbraith, J. S. Garfield, K. A. Giese, C. E. Golberg, B. A. Higley, K. J. Hull, L. J. Johnson, R. P. Knight, J. S. Layman, R. S. Marusich, R. J. Parazin, M. G. Piepho, E. J. Slaathaug, T. L. Waldo, and C. E. Worcester, 1991, Systems Engineering Study for the Closure of Single Shell Tanks, Draft A, Volumes 1-6, WHC-EP-405, Westinghouse Hanford Company, Richland, Washington.

Deleplaine, J. D., and R. F. McCullough, 1955, "Pilot Plant for Decomposing Ammonium Sulfate Uses Moving Bed," Chemical Engineering Progress, Vol. 51, No. 11, p. 499 November.

Hendrickson, D. W., 1996, Engineering Study of the Potential Uses of Salts from Selective Crystallization of Hanford Tank Wastes, WHC-EP-0904, April, Westinghouse Hanford Company, Richland, Washington.

Herting, D. L., 1993, Clean Salt Process Applied to Double Shell Slurry (Tank 101-SY), WHC-SD-WM-DTR-029, Rev. 0, August 23, Westinghouse Hanford Company, Richland, Washington.

Herting, D. L., 1994, Crystal Growth and Occlusion Studies Supporting Sodium Nitrate Fractional Crystallization, WHC-SD-WM-DTR-035, Rev. 0, August 8, Westinghouse Hanford Company.

Herting, D. L., 1995, Clean Salt Disposition Options, WHC-SD-WM-ES-333, Rev. 0, March 29, Westinghouse Hanford Company, Richland, Washington.

Herting, D. L., and T. R. Lunsford, 1994, Significant Volume Reduction of Tank Waste by Selective Crystallization: 1994 Annual Report, WHC-SD-WM-TI-643, Rev. 0, September 27, Westinghouse Hanford Company, Richland, Washington.

Lunsford, T. R., 1994, Clean Salt Integrated Flowsheet, WHC-SD-WM-DTR-036, Rev. 0, September 27, Westinghouse Hanford Company, Richland, Washington.

MacLean, G. T., 1996, The Clean Salt Process - Preliminary Design and Economic Evaluation, WHC-EP-0917, October, Westinghouse Hanford Company, Richland, Washington.

"Natural Background Radiation in the United States," NCRP Report No. 45. 
Peters, F. A., P. W. Johnson, and R. C. Kirby, Methods for Producing Alumina from Clay, U.S. Bureau of Mines Report of Investigations 6573.

Stordeur, R. T., 1986, Hanford Defense Waste Disposal Alternatives: Engineering Support Data for HDW-EIS, RHO-RE-ST-30P, Rockwell Hanford Operations, Richland, Washington. 
WHC-EP-0915

APPENDIX A

SOLUBILITY PHASE DIAGRAMS FOR THE SYSTEMS $\mathrm{NaNO}_{3} / \mathrm{Al}\left(\mathrm{NO}_{3}\right)_{3} / \mathrm{H}_{2} \mathrm{O}$ AND

$\mathrm{NaF} / \mathrm{Na}_{3} \mathrm{PO} / \mathrm{NaOH} / \mathrm{H}_{2} \mathrm{O}$ 
WHC-EP-0915

This page intentionally left blank. 
From: Process Chemistry and Statistics

Phone: $\quad 373-2532$ T6-09

Date: August 29, 1996

Subject: SOLUBILITY PHASE DIAGRAM REPORT FOR MILESTONE B1

To:

G. T. Berlin

H6-34

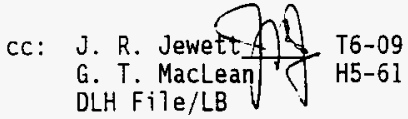

References: (1) Technical Task Plan RL4-6-C3-41, "Selective Crystaliization of Tank Supernatant Liquid," D. L. Herting, dated September 22, 1995.

(2) Sasiawsky, A. J., Ettinger J. L., and Eserowa, E. A., Zhur. Obs. Khimi i (in Russian), 7, 2410-2416 (1937).

(3) "Solubilities of Inorganic and Metal-Organic Compounds," 4th ed., W. F. Linke, American Chemical Society, 1965.

(4) Internal Memo, M. J. Duchsherer to D. L. Herting, "Test Results Supporting Phase Diagrams for ANN-NaNO $3-\mathrm{HNO}_{3}-\mathrm{H}_{2} \mathrm{O}$ Equilibria," dated July 31, 1995.

(5) WHC-SD-WM-DTR-035, REV. 0, "Crystal Growth and Occlusion Studies Supporting Sodium Nitrate Fractional Crystallization," D. L. Herting, August 8, 1994 (Appendix A).

(6) Mason, C. W., and E. B. Ashcraft, Industrial and Engineering Chemistry, 31 (6), 768, June, 1939.

This internal memo satisfies the requirements of Milestone Bl in the Technical Task Plan (TTP), Reference 1. The milestone title is "Issue Report on Solubility Phase Diagrams". The description is: "Issue report on two solubility phase diagrams for the $\mathrm{NaNO}_{3} / \mathrm{Al}\left(\mathrm{NO}_{3}\right)_{3} / \mathrm{HNO}_{3} / \mathrm{H}_{2} \mathrm{O}$ system and the $\mathrm{Na}_{3} \mathrm{PO}_{4} / \mathrm{NaF} / \mathrm{NaOH} / \mathrm{H}_{2} \mathrm{O}$ system". 
Page 2

August 29, 1996

$\mathrm{NaNO}_{3} / \mathrm{Al}\left(\mathrm{NO}_{3}\right)_{3} / \mathrm{HNO}_{3} / \mathrm{H}_{2} \mathrm{O}$ SYSTEM

The process flowsheet for the Clean Salt Process begins with acidification of the low level liquid fraction of tank waste, i.e., the supernatant

liquids from the tank and the sludge washing operation. Evaporation of the acidified solution leads to precipitation of the major salt present in the system, $\mathrm{NaNO}_{3}$.

Some waste types, such as double shell slurry (DSS) and DSS Feed (DSSF), contain significant concentrations of sodium aluminate, which is converted upon acidification with nitric acid to sodium nitrate and aluminum nitrate. Near the end of the evaporation process, it is likely that some aluminum nitrate nonahydrate (ANN) would co-precipitate with the $\mathrm{NaNO}_{3}$. The objective of studying the solubility phase diagram for the $\mathrm{NaNO}_{3} / \mathrm{Al}\left(\mathrm{NO}_{3}\right)_{3} / \mathrm{HNO}_{3} / \mathrm{H}_{2} \mathrm{O}$ system is to be able to predict the conditions under which the two nitrate salts would co-precipitate. This co-precipitation could be no problem or a big problem, depending on the ultimate fate or use of the product salt.

Some excellent literature data are available (Reference 2) that describe the entire subject phase diagram at low temperatures $\left(0\right.$ and $\left.20{ }^{\circ} \mathrm{C}\right)$. Other literature data (Reference 3 ) describe portions of the phase diagram at higher temperatures. To further probe the temperature effects on the full system, several computer runs were done using the Environmental Simutation Program (ESP) produced by OLI Systems, Inc.

A brief laboratory study was done in 1995 (Reference 4) to expand on the data for the full system at higher temperatures. Due to experimental difficulties and inconsistencies, none of this laboratory data is used in the current report.

Table 1 contains the literature data for the system $\mathrm{NaNO}_{3} / \mathrm{Al}\left(\mathrm{NO}_{3}\right)_{3} / \mathrm{HNO}_{3} / \mathrm{H}_{2} \mathrm{O}$. The subset of data for the system $\mathrm{NaNO}_{3} / \mathrm{Al}_{(}\left(\mathrm{NO}_{3}\right)_{3} / \mathrm{H}_{2} \mathrm{O}$ (no excess $\mathrm{HNO}_{3}$ ) over the temperature range 20 to $60^{\circ} \mathrm{C}$ are $\mathrm{p}$ lotted in Figure 1 . To interpret this figure, imagine placing a point on the graph for a clear solution having the composition $10 \% \mathrm{Al}\left(\mathrm{NO}_{3}\right)_{3}$ and $20 \% \mathrm{NaNO}_{3}$ (the remaining $70 \%$ being $\mathrm{H}_{2} \mathrm{O}$ ). The effect of evaporating that solution at, say, $20{ }^{\circ} \mathrm{C}$ can be found by extending a line from the origin through the data point. The solution becomes more concentrated in both $\mathrm{NaNO}_{3}$ and $\mathrm{Al}\left(\mathrm{NO}_{3}\right)_{3}$ as the water evaporates until the extended line reaches the solubility curve for $\mathrm{NaNO}_{3}$ at approximately $13 \% \mathrm{Al}\left(\mathrm{NO}_{3}\right)_{3}$ and $28 \% \mathrm{NaNO}_{3}$. As the evaporation continues, $\mathrm{NaNO}_{3}$ precipitates while the composition of the solution follows the solubility curve downward (i.e., the $\mathrm{Al}\left(\mathrm{NO}_{3}\right)_{3}$ in solution becomes more concentrated and the $\mathrm{NaNO}_{3}$ in solution becomes less concentrated) until the solution composition reaches the invariant point. At that point, both salts will precipitate as the water evaporates, keeping the solution composition constant. 
Page 3

August 29, 1996

Table 1. Literature Solubility Data (References 2 and 3 ) $\mathrm{NaNO}_{3} / \mathrm{Al}\left(\mathrm{NO}_{3}\right)_{3} / \mathrm{HNO}_{3} / \mathrm{H}_{2} \mathrm{O}$ system weight percent

\begin{tabular}{|c|c|c|c|c|}
\hline Temp, ${ }^{\circ} \mathrm{C}$ & $\mathrm{Al}\left(\mathrm{NO}_{3}\right)_{3}$ & $\mathrm{NaNO}_{3}$ & $\mathrm{HNO}_{3}$ & Solid \\
\hline 20 & 40 & 0 & 0 & A \\
\hline 20 & 38.56 & 0 & 0 & A \\
\hline 20 & 37.3 & 5.35 & 0 & A \\
\hline 20 & 35.68 & 10.31 & 0 & $\mathrm{~A}+\mathrm{N}$ \\
\hline 20 & 32.29 & 11.66 & 0 & $\mathrm{~N}$ \\
\hline 20 & 19.15 & 22.22 & 0 & $\mathrm{~N}$ \\
\hline 20 & 12.47 & 29.34 & 0 & $N$ \\
\hline 20 & 12.19 & 29.65 & 0 & $N$ \\
\hline 20 & 0 & 46.27 & 0 & $N$ \\
\hline 20 & 31 & 0 & 10 & $\mathrm{~A}$ \\
\hline 20 & 0 & 23.69 & 18.98 & $\mathrm{~N}$ \\
\hline 20 & 27.1 & 0 & 15.45 & $\mathrm{~A}$ \\
\hline 20 & 23 & 0 & 20 & A \\
\hline 20 & 18.46 & 8.14 & 23.32 & $\mathrm{~A}+\mathrm{N}$ \\
\hline 40 & 44 & 0 & 0 & A \\
\hline 40 & 46.25 & 0 & 0 & A \\
\hline 40 & 42.65 & 0 & 0 & A \\
\hline 40 & 38.71 & 10.38 & 0 & $\mathrm{~A}+\mathrm{N}$ \\
\hline 40 & 0 & 51.2 & 0 & $N$ \\
\hline 40 & 36 & 0 & 10 & A \\
\hline 40 & 28.63 & 0 & 16.41 & A \\
\hline 40 & 29 & 0 & 20 & A \\
\hline 60 & 50.95 & 0 & 0 & A \\
\hline 60 & 47.5 & 0 & 0 & $A$ \\
\hline 60 & 44.38 & 9.65 & 0 & $\mathrm{~A}+\mathrm{N}$ \\
\hline 60 & 0 & 55.5 & 0 & $\mathrm{~N}$ \\
\hline 60 & 37.58 & 0 & 9.76 & A \\
\hline 60 & 40.5 & 0 & 10 & A \\
\hline 60 & 34.5 & 0 & 20 & $\mathrm{~A}$ \\
\hline
\end{tabular}

${ }^{1} \mathrm{~A}=\mathrm{Al}\left(\mathrm{NO}_{3}\right)_{3} \cdot 9 \mathrm{H}_{2} \mathrm{O} ; \mathrm{N}=\mathrm{NaNO}_{3} ; \mathrm{A}+\mathrm{N}=$ both salts present in solid phase 
Figure 1. Literature Data for the System

$\mathrm{NaNO}_{3}-\mathrm{Al}\left(\mathrm{NO}_{3}\right)_{3}-\mathrm{H}_{2} \mathrm{O}$

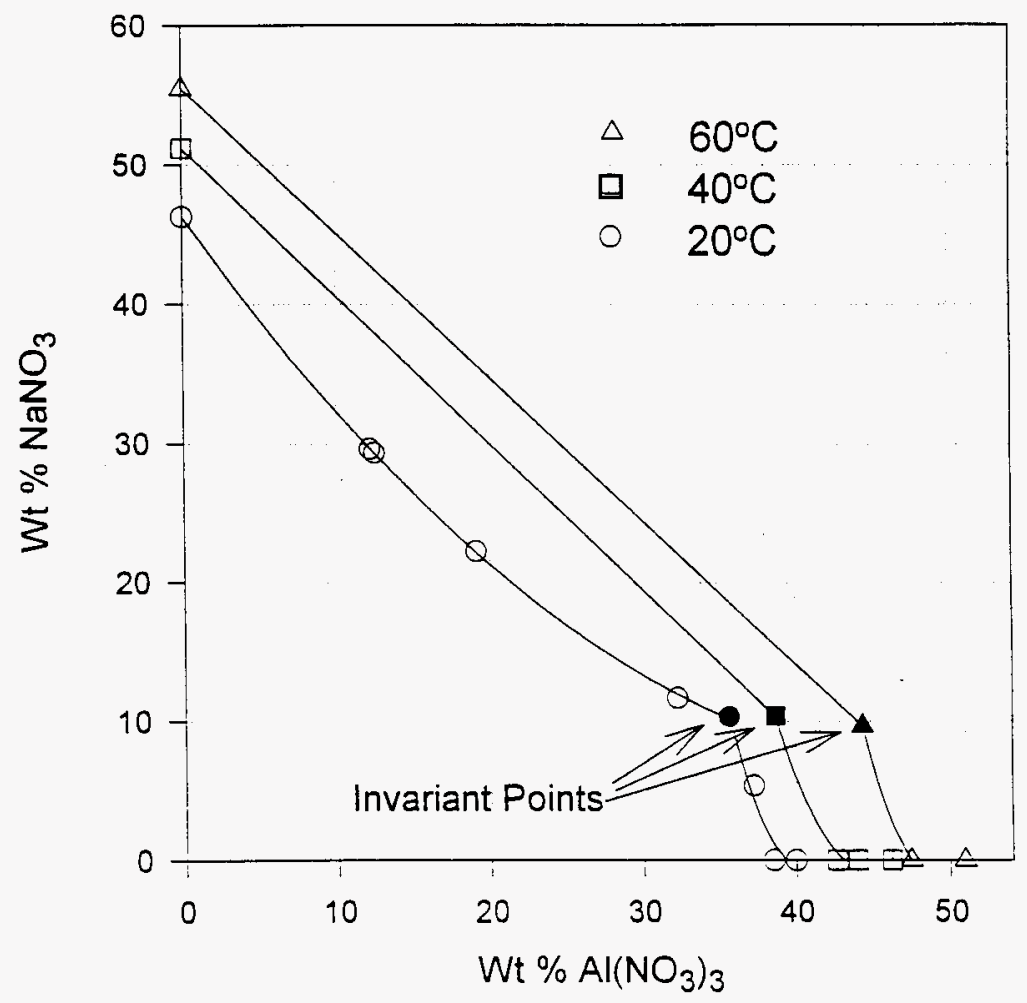


It is apparent from Figure 1 that the presence of aluminum has a large effect on the solubility of $\mathrm{NaNO}_{3}$. At $20{ }^{\circ} \mathrm{C}, \mathrm{NaNO}_{3}$ solubility falls from $46 \%$ at zero. aluminum nitrate to $10 \%$ at high $\mathrm{Al}\left(\mathrm{NO}_{3}\right)_{3}$. Conversely, the presence of $\mathrm{NaNO}_{3}$ has a relatively small effect on the solubility of $\mathrm{Al}\left(\mathrm{NO}_{3}\right)_{3}$. Looked at another way, it is possible to dissolve a large amount of $\mathrm{AT}\left(\mathrm{NO}_{3}\right)_{3}$ in a $\mathrm{NaNO}_{3}$ solution, but it is possible to dissolve only a small amount of $\mathrm{NaNO}_{3}$ in an $\mathrm{Al}_{1}\left(\mathrm{NO}_{3}\right)_{3}$ solution. If the objective of the process is to remove as much $\mathrm{NaNO}_{3}$ from the waste as possible without precipitating $\mathrm{Al}\left(\mathrm{NO}_{3}\right)_{3}$, then this situation is fortunate.

The solubility curves at 40 and $60{ }^{\circ} \mathrm{C}$ in Figure 1 are slightly misleading. They should be curved more or less like the one at $20^{\circ} \mathrm{C}$, but there are no data points between the $y$-axis and the invariant points. The computergenerated data (Figure 2), while not matching the invariant point compositions very well, at least show the proper curvatures. (Oniy the $\mathrm{NaNO}_{3}$ solubility curves are plotted in Figure 2. However, the invariant points are close enough to the pure-Al $\left(\mathrm{NO}_{3}\right)_{3} / \mathrm{H}_{2} \mathrm{O}$ solubility points that the A) $\left(\mathrm{NO}_{3}\right)_{3}$ solubility curve could be added by making a very short interpolation.)

Personnel at OLI Systems have been apprised of the poor fit of the computer generated data near the invariant points. They have responded that they are aware of the problem and will be rectifying it in the near future.

The data in Table 1 were evaluated statistically by regression anaiysis to develop equations to predict the solubilities of $\mathrm{NaNO}_{3}$ and $\mathrm{Al}\left(\mathrm{NO}_{3}\right)_{3}$ as a function of temperature, nitric acid concentration, and each other. The data points in Table 1 that had $\mathrm{NaNO}_{3}$ or $\mathrm{Al}\left(\mathrm{NO}_{3}\right)_{3}+\mathrm{NaNO}_{3}$ as the solid phase were used for the $\mathrm{NaNO}_{3}$ solubility equation. The data points that had $\mathrm{Al}\left(\mathrm{NO}_{3}\right)_{3}$ or $\mathrm{Al}\left(\mathrm{NO}_{3}\right)_{3}+\mathrm{NaNO}_{3}$ as the solid phase were used for the $\mathrm{Al}\left(\mathrm{NO}_{3}\right)_{3}$ solubility equation. The equations are:

$$
\begin{aligned}
& N=56.1+2.42 T^{1 / 2}+4.16 A^{1 / 2}+10.0 H^{1 / 2}, \text { with } R^{2}=0.9988 \\
& A=82.6+0.265 T-0.523 H-14.0 N^{1 / 2}, \text { with } R^{2}=0.9674
\end{aligned}
$$

where $\mathrm{N}=$ weight percent $\mathrm{NaNO}_{3}$ in liquid phase, $\mathrm{A}=$ weight percent $\mathrm{Al}\left(\mathrm{NO}_{3}\right)_{3}$ in 7 iquid phase, $\mathrm{H}=$ weight percent $\mathrm{HNO}_{3}, \mathrm{~T}=$ temperature in ${ }^{\circ} \mathrm{C}$, and $\mathrm{R}=$ adjusted regression coefficient.

The effect of excess nitric acid on the solubility of $\mathrm{Al}\left(\mathrm{NO}_{3}\right)_{3}$ is shown in Figure $3 \mathrm{a}$, and its effect on $\mathrm{NaNO}_{3}$ solubility in Figure $3 \mathrm{~b}$, using the data from Table 1. The Clean Salt Process is expected to involve $\mathrm{HNO}_{3}$ concentrations no higher than one or two weight percent $\mathrm{HNO}_{3}$, so the acid concentration should have little effect on the solubility of either salt. 
Figure 2. ESP Data for the System

$\mathrm{NaNO}_{3}-\mathrm{Al}\left(\mathrm{NO}_{3}\right)_{3}-\mathrm{H}_{2} \mathrm{O}$

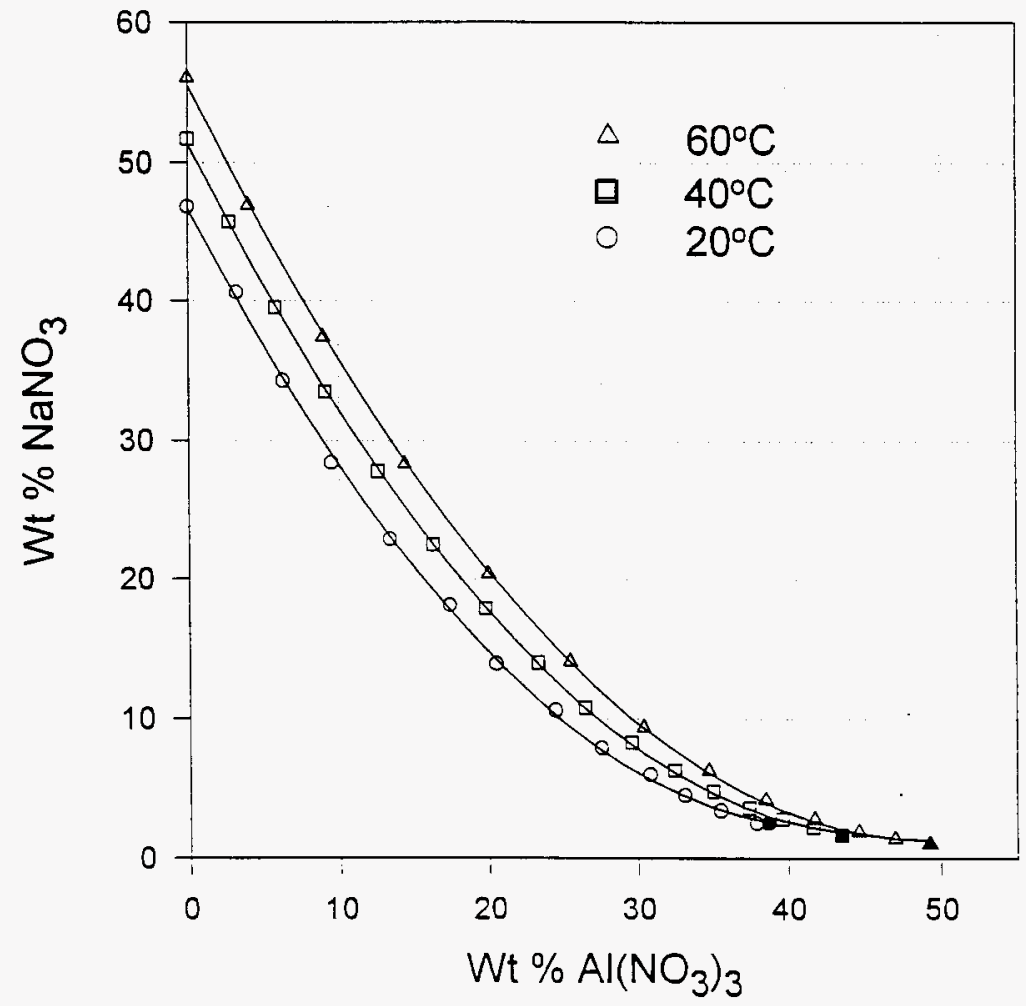


Page 7

August 29, 1996

Figure 3a. Effect of $\mathrm{HNO}_{3}$ on $\mathrm{Al}\left(\mathrm{NO}_{3}\right)_{3}$ Solubility

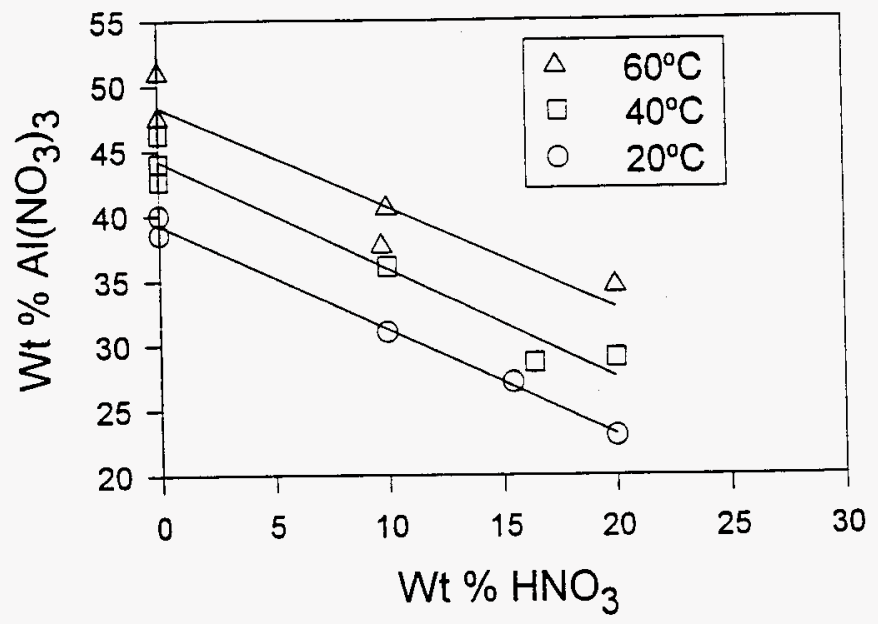

Figure 3b. Effect of $\mathrm{HNO}_{3}$ on $\mathrm{NaNO}_{3}$ Solubility

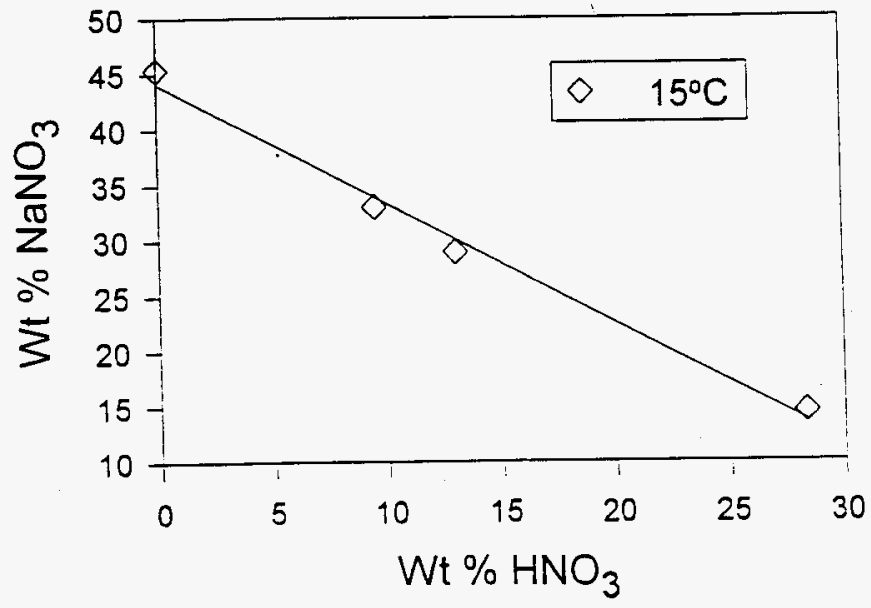


Page 8

August 29, 1996

$\mathrm{NaF} / \mathrm{Na}_{3} \mathrm{PO}_{4} / \mathrm{NaOH} / \mathrm{H}_{2} \mathrm{O}$ SYSTEM

Sludge from tank 241-U-110 (110-U) was the first radioactive waste to be used for testing the Clean Salt Process (Reference 5 ). The sludge was washed with water at approximately $60{ }^{\circ} \mathrm{C}$ for several hours to dissolve the water-soluble sodium salts in the sludge. When the supernatant liquid cooled to room temperature, an unexpected solid had formed. The solid consisted of highly regular octahedral crystals that were identified by polarized light microscopy (PLM) and by $X$-ray diffraction (XRD) as sodium fluoride diphosphate hydrate, $\mathrm{Na}_{7} \mathrm{~F}\left(\mathrm{PO}_{4}\right)_{2} \cdot 19 \mathrm{H}_{2} \mathrm{O}$.

No attempt was made at that time to recrystallize and decontaminate the double salt. Plans were made, however, to incorporate a step into the process flowsheet to recover the double salt from waste streams that were high in fluoride and/or phosphate, both of which are problematic for vitrification.

Knowledge of the $\mathrm{NaF} / \mathrm{Na}_{3} \mathrm{PO}_{4} / \mathrm{NaOH} / \mathrm{H}_{2} \mathrm{O}$ system is necessary for predicting the conditions under which the double salt forms, and the conditions necessary to recrystallize and decontaminate the salt. During the current fiscal year, parallel efforts were made to extract non-radioactive $\mathrm{Na}_{7} \mathrm{~F}\left(\mathrm{PO}_{4}\right)_{2} \cdot 19 \mathrm{H}_{2} \mathrm{O}$ crystals from tank $110-\mathrm{U}$ sludge and to perform laboratory experiments to define the $\mathrm{NaF} / \mathrm{Na}_{3} \mathrm{PO}_{4} / \mathrm{NaOH} / \mathrm{H}_{2} \mathrm{O}$ system solubility phase diagram.

The laboratory solubility measurements were successful in defining a rough phase diagram, but some of the measurements may have been biased by using glass vessels that might have reacted with the solutes. Before new measurements could be made, however, data from the tank 110-U experiments clearly demonstrated that the double salt could not be decontaminated from ${ }^{90} \mathrm{Sr}$ (and probably some other radionuclides), and the decision was made not to refine the solubility work.

Tank 110-U Test and Results - The sample used for this test was an archived core composite sample labeled $S-110 U$ from a tank $110-U$ core sample taken in 1989 (cf. page 112 in controlled laboratory notebook WHC-N-656-1). The sample was found to have dried to a powdery solid during storage. The sample was stirred to mix the solids, and then $251 \mathrm{~g}$ of the solids were transferred into a 1 L Erlenmeyer flask to which $502 \mathrm{~g}$ of water was added. The contents of the flask were maintained at approximately $55^{\circ} \mathrm{C}$, with stirring, for at least 3 hours, then transferred into twelve $50 \mathrm{~mL}$ centrifuge cones. The cones were placed in a heated centrifuge $\left(55^{\circ} \mathrm{C}\right)$, and centrifuged for at least one hour. The supernatant liquids were decanted into a single $500 \mathrm{~mL}$ plastic bottle labeled "110-U Water Wash".

The theoretical yield of $\mathrm{Na}_{7} \mathrm{~F}\left(\mathrm{PO}_{4}\right)_{3} \cdot 19 \mathrm{H}_{2} \mathrm{O}$ was $22 \mathrm{~g}$, based on the fluoride and phosphate analyses of the tank $110-U$ sludge. The actual weight of crystals recovered from the concentrated and cooled "110-U Water Wash" was $19.2 \mathrm{~g}$. The crystals were identified by $\mathrm{PLM}$ as $\mathrm{Na}_{7} \mathrm{~F}\left(\mathrm{PO}_{4}\right)_{2} \cdot 19 \mathrm{H}_{2} \mathrm{O}$. 
August 29, 1996

The product was recrystallized five times from water. The activity of the product (as measured by a Geiger-Müller counter) decreased as expected for the first recrystallization, but did not decrease during any subsequent recrystallization. The product remaining after the fifth recrystallization was analyzed for ${ }^{137} \mathrm{Cs}$ by gamma energy analysis (GEA), total activity by liqu iscintiliation, and ${ }^{90} \mathrm{Sr} /{ }^{90} \mathrm{Y}$ and ${ }^{99} \mathrm{TC}$ by separation methods. Results were:

$$
\begin{array}{ll}
\text { Total Activity } & 3.2 \times 10^{-2} \mu \mathrm{Ci} / \mathrm{g} \\
{ }^{90} \mathrm{Sr} /{ }^{90} \mathrm{Y} & 1.6 \times 10^{-2} \mu \mathrm{Ci} / \mathrm{g} \\
{ }^{137} \mathrm{Cs} & 1.4 \times 10^{-5} \mu \mathrm{Ci} / \mathrm{g} \\
{ }^{99} \mathrm{TC} & <1.1 \times 10^{-3} \mu \mathrm{Ci} / \mathrm{g}
\end{array}
$$

Activities measured in the feed solution (110-U Water Wash) were $0.113 \mu \mathrm{Ci} / \mathrm{g}$ for ${ }^{90} \mathrm{Sr}$ and $2.07 \mu \mathrm{Ci} / \mathrm{g}$ for ${ }^{137} \mathrm{Cs}$, so decontamination factors (feed activity divided by product activity) were 14 for ${ }^{90} \mathrm{Sr}$ and $7 \mathrm{million}$ for ${ }^{137} \mathrm{Cs}$.

The activity as a function of number of recrystallizations must have occurred as depicted in Figure 4. The double salt was separated from ${ }^{137} \mathrm{Cs}$ as expected, but there was virtually no decontamination of the salt from ${ }^{90} \mathrm{Sr}$. The following theory was developed to explain the inability to remove the ${ }^{90} \mathrm{Sr}$.

When a salt is recrystallized, impurities are removed from the salt, as long as the impurities are either more or less soluble than the salt. When the salt is dissolved in water, impurities that are less soluble than the salt remain in the solid phase, and are removed when the solution is filtered. When the filtrate is evaporated and/or cooled, the salt crystallizes, and impurities that are more soluble than the salt stay in solution. When the slurry is filtered to recover the salt, the impurities in solution pass on through the filter.

This purification system has been shown to work very well for separating $\mathrm{NaNO}_{3}$ from all of the radionuclides present in radioactive waste. This is possible because all of the nitrate salts of the radionuclides are more soluble than $\mathrm{NaNO}_{3}$, at least at the concentration levels of the radionuclides in the waste. Every time the $\mathrm{NaNO}_{3}$ salt is recrystallized from water, the radionuclides stay in the liquid phase and are separated from the product salt. 
Figure 4. Recrystallization of $\mathrm{Na}_{7} \mathrm{~F}\left(\mathrm{PO}_{4}\right)_{2} \cdot 19 \mathrm{H}_{2} \mathrm{O}$ from Tank 110-U Sludge

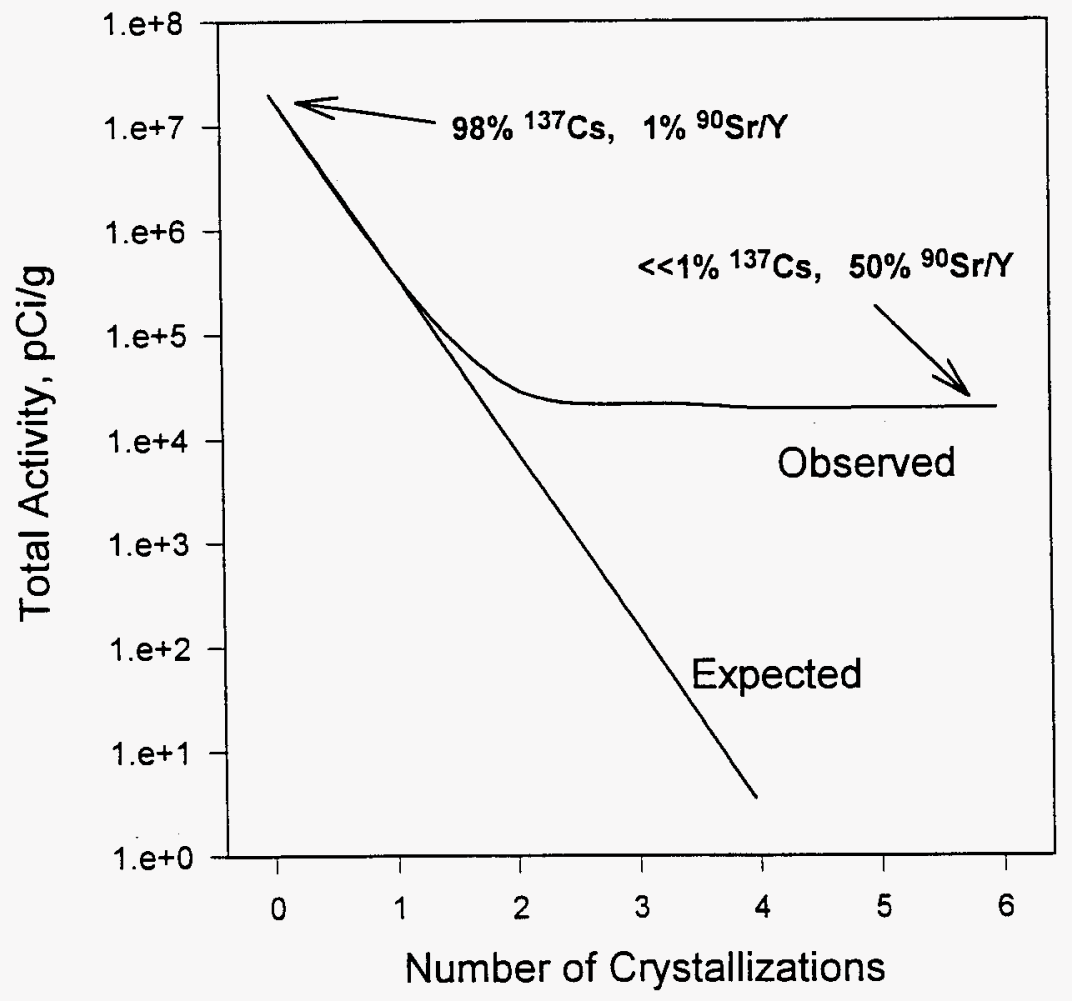


Page 11

August 29, 1996

In the case of the fluoride/phosphate double salt, the process failed because $\mathrm{SrF}_{2}$ and $\mathrm{Sr}_{3}\left(\mathrm{PO}_{4}\right)_{2}$ are virtually insoluble in water, but are present at concentrations too low to form a pure solid phase. In effect, the $\mathrm{Sr}^{2+}$ ions are physically too far apart in solution to produce a $\mathrm{SrF}_{2}$ embryo, or aggregate, larger than the critical nucleus size, i.e., a size large enough to grow into a solid phase. However, the $\mathrm{Sr}^{2+}$ ions can capitalize on an opportunity, so to speak, and precipitate with the fiuoride and/or phosphate ions that are on the surface of the growing $\mathrm{Na}_{7} \mathrm{~F}\left(\mathrm{PO}_{4}\right)_{2} \cdot 19 \mathrm{H}_{2} \mathrm{O}$ crystals. When the crystals are dissolved in water, the $\mathrm{Sr}^{2+}$ ions are sti 17 too far apart to form individual solid particles of $\mathrm{SrF}_{2}$ or $\mathrm{Sr}_{3}\left(\mathrm{PO}_{4}\right)_{2}$, and so they remain in the liquid phase along with the dissolved double sait, only to re-form the solid when the salt recrystaliizes. Thus, the ${ }^{90} \mathrm{Sr}$ dissolves when the double salt dissolves and "crystallizes" when the double salt crystallizes, making separation of the double salt from the ${ }^{90} \mathrm{Sr}$ impossible. A fluoride/phosphate salt recovery process could be considered again in the future if it is combined with a ${ }^{90} \mathrm{Sr}$ recovery process such as ion exchange.

Solubility Phase Diagrams - The sodium fluoride diphosphate double salt was first positively identified and described by Mason and Ashcraft (Reference 6 ) in 1939. Very little literature data on the solubility phase diagram exists, but the general shape of the diagram is certainly as described by Mason and Ashcraft, reproduced here as Figure 5 . This is a "distorted" diagram, in that the axes are not linear. The figure is intended to show only the relationships among the regions, and not to show quantitative data.

Point $D$ in the figure represents the solubility of $\mathrm{NaF}$ in water, at $4 \%$ by weight $\mathrm{NaF}$. Point $\mathrm{A}$ represents the solubility of $\mathrm{Na}_{3} \mathrm{PO}_{4} \cdot 12 \mathrm{H}_{2} \mathrm{O}$ in water, at $12 \%$ hydrated salt. Point $E$ represents the point at which the anhydrous $\mathrm{Na}_{3} \mathrm{PO}_{4}$ begins to form. The diagram is over-simplified in that it ignores the intermediate hydrated forms of $\mathrm{Na}_{3} \mathrm{PO}_{4}$. Points $\mathrm{B}$ and $\mathrm{C}$ are invariant points, as explained below.

Each region of the diagram is labeled with the phases that are stable within the region. Any mixture having a composition that falls on the graph within region S+F will contain solid $\mathrm{NaF}$ and a solution having a composition that falls somewhere on the line C-D. The slope of the line C-D implies that the solubility of $\mathrm{NaF}$ is reduced sharply when a small amount of $\mathrm{Na}_{3} \mathrm{PO}_{4}$ is added.

Any mixture within region $S+F+F P$ will contain solid NaF, solid $\mathrm{Na}_{7} \mathrm{~F}\left(\mathrm{PO}_{2}\right)_{4} \cdot 19 \mathrm{H}_{2} \mathrm{O}$, and a liquid phase having the composition of the invariant point $C^{2}$. With two solid phases present, there are no degrees of freedom left in the system, so the composition of the solution is constant.

Within region S+FP, there is one solid phase, so the solution composition Can fall anywhere on the line $B-C$. There are two solid phases within region $S+F P+P$, so the solution composition is fixed at point $B$. The liquid phase within region $S+P$ is variabie along the line $A-B$. The slope of the line $A-B$ implies that the solubility of $\mathrm{Na}_{3} \mathrm{PO}_{4} \cdot 12 \mathrm{H}_{2} \mathrm{O}$ is reduced sharply when small amounts of NaF are added. 
The exact positions of points $A, D$ and $E$ are known from literature data, but the positions of points $B$ and $C$ are not known with any accuracy. The first phase diagram experiment was an attempt to determine the approximate locations of points $B$ and $C$. In this experiment, $1 M$ stock solutions of $N a F$ and $\mathrm{Na}_{3} \mathrm{PO}$, were prepared. (The $\mathrm{Na}_{3} \mathrm{PO}_{4}$ stock solution had to be heated gently to get all of the $\mathrm{Na}_{3} \mathrm{PO}_{4}$ in solution.) The stock solutions were mixed together in polycarbonate sample vials, and the crystals that formed were examined by PLM. [Crystals of NaF and $\mathrm{Na}_{7} \mathrm{~F}\left(\mathrm{PO}_{2}\right)_{4} \cdot 19 \mathrm{H}_{2} \mathrm{O}$ both belong to the cubic crystal system, but can be distinguished with the PLM because their different refractive indexes lead to different levels of contrast between the crystals and the supernatant liquid. Crystals of $\mathrm{Na}_{3} \mathrm{PO}_{4} \cdot 12 \mathrm{H}_{2} \mathrm{O}$ are easily distinguished by their polarized light interference colors, because they belong to the hexagonal crystal system, and thus are anisotropic.]

A series of mixtures were prepared at ambient room temperature (approximately $25{ }^{\circ} \mathrm{C}$ ) by mixing $10 \mathrm{~mL}$ of the $\mathrm{NaF}$ solution with $X \mathrm{~mL}$ of the $\mathrm{Na}_{3} \mathrm{PO}_{4}$ stock solution, where $X=1,2,3, \ldots 10 \mathrm{~mL}$. The samples were 1 abeled $10 / 1,10 / 2 \ldots 10 / 10$. A second series of samples was prepared and labeled $9 / 10,8 / 10,7 / 10 \ldots 1 / 10$, where the first number is the volume of $\mathrm{NaF}$ stock solution and the second number is the volume of $\mathrm{Na}_{3} \mathrm{PO}_{4}$ stock solution. The two series together were intended to cover the line A-D in Figure 5. The results were as follows.

Sample vial 10/1 (all numbers are volume $\mathrm{NaF}$ stock solution/volume $\mathrm{Na}_{3} \mathrm{PO}_{4}$ stock solution) did not produce solids. Samples $10 / 2,10 / 3,10 / 4 \ldots 10 / 10$, $9 / 10,8 / 10 \ldots 4 / 10$ all contained exclusively $\mathrm{Na}_{7} \mathrm{~F}\left(\mathrm{PO}_{2}\right)_{5} \cdot 19 \mathrm{H}_{2} \mathrm{O}$ crystals, indicating that these mixtures all fell within region $\mathrm{S}+\mathrm{FP}$ in Figure 5 . Samples $3 / 10,2 / 10$ and $1 / 10$ produced mixtures of $\mathrm{Na}_{7} \mathrm{~F}\left(\mathrm{PO}_{2}\right)_{4} \cdot 19 \mathrm{H}_{2} \mathrm{O}$ and $\mathrm{Na}_{3} \mathrm{PO}_{4} \cdot 12 \mathrm{H}_{2} \mathrm{O}$ crystals, so these mixtures all fall within the region $S+F P+P$. This implies that point $\mathrm{B}$ in Figure 5 falls very close to the $\mathrm{H}_{2} \mathrm{O}-\mathrm{Na}_{3} \mathrm{PO}_{4}$ axis, and the region $S+P$ is very small. In other words, it takes very little fluoride to form $\mathrm{Na}_{7} \mathrm{~F}\left(\mathrm{PO}_{2}\right)_{4} \cdot 19 \mathrm{H}_{2} \mathrm{O}$ crystals in a concentrated phosphate solution.

In order to estimate the position of 1 ine $B-C$ in Figure 5 , the liquid fractions from samples $10 / 5,10 / 10$ and $5 / 10$ were analyzed by ion chromatography (IC) for fluoride and phosphate concentrations. A]l three points should fall on the line B-C. Analytical results are shown in. Tabie 2. The data do not define the locations of points $B$ and $C$, but they do give a good indication of where the line B-C is located. They clearly show that the solubility of $\mathrm{NaF}$ is reduced by more than a factor of 10 (from over $4 \%$ by weight to less than $0.3 \%$ ) in the presence of $\mathrm{Na}_{3} \mathrm{PO}_{4}$; converse $1 \mathrm{y}$, the solubility of $\mathrm{Na}_{3} \mathrm{PO}_{4}$ is reduced from $12 \%$ in the absence of fluoride to less than $1.8 \%$ in high fluoride solutions. 
G. T. Berlin

Page 13

August 29, 1996

Figure 5. Distorted Diagram of the $\mathrm{NaF} / \mathrm{Na}_{3} \mathrm{PO}_{4} / \mathrm{H}_{2} \mathrm{O}$ System

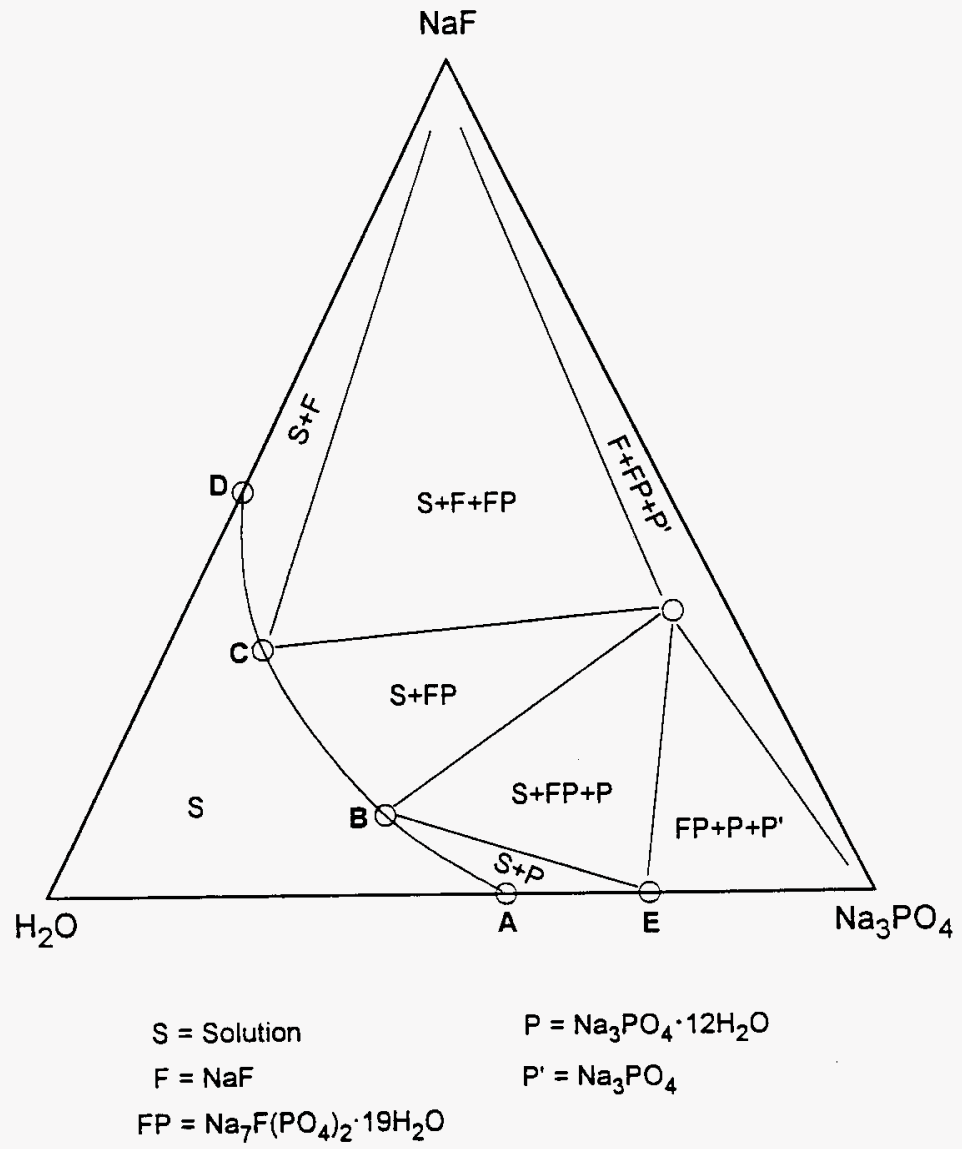


Table 2. Composition of Liquid Phase in Mixed Fluoride/Phosphate Samples

\begin{tabular}{|c|c|c|c|c|}
\hline F1uoride/Phosphate volumes: & $10 / 5$ & $10 / 10$ & $5 / 10$ \\
\hline Customer ID: & DH51A & DH51B & DH51C \\
\hline Labcore ID: & S96R000004 & 596 R000005 & S96R000006 \\
\hline $\mathrm{F}^{-}$ & $\mu \mathrm{g} / \mathrm{mL}$ & 8,300 & 4,790 & 1.670 \\
\hline $\mathrm{PO}_{4}^{3-}$ & $\mu \mathrm{g} / \mathrm{mL}$ & 10,900 & 16,200 & 27,500 \\
\hline Density & $\mathrm{g} / \mathrm{mL}$ & 1.05 & 1.10 & 1.13 \\
\hline $\mathrm{NaF}$ & $\mathrm{WT} \%$ & 1.7 & 1.0 & 0.3 \\
\hline $\mathrm{Na}_{3} \mathrm{PO}_{2}$ & WT $\%$ & 1.8 & 2.5 & 4.2 \\
\hline \\
\hline
\end{tabular}

The second experiment was designed to test the effects of temperature, ionic strength, and hydroxide concentration on the solubility of the double salt in water. The fluoride/phosphate ratio was not altered during these tests, so the data represent how a single point on the line B-C in Figure 5 varies as a function of the parameters just mentioned.

A Targe batch of double salt crystals was prepared by dissolving 0.50 mole of reagent grade $\mathrm{Na}_{3} \mathrm{PO}_{4} \cdot 12 \mathrm{H}_{2} \mathrm{O}$ in $400 \mathrm{~mL}$ warm $\mathrm{H}_{2} \mathrm{O}$ and filtering, dissolving 0.25 mole of reagent grade $\mathrm{NaF}$ in $250 \mathrm{~mL}$ warm $\mathrm{H}_{2} \mathrm{O}$ and filtering, and mixing the two clear solutions. A total of $168 \mathrm{~g}$ of $\mathrm{Na}_{7} \mathrm{~F}\left(\mathrm{PO}_{2}\right)_{4} \cdot 19 \mathrm{H}_{2} \mathrm{O}$ crystals was recovered, compared to the theoretical yield of $178 \mathrm{~g}$. The crystals were identified by PLM. A sample of $5.008 \mathrm{~g}$ of crystals dissolved in water to $100 \mathrm{~mL}$ total volume was analyzed by $\mathrm{IC}_{3}$ for $\mathrm{F}^{-}$and $\mathrm{PO}_{4}{ }^{3-}$ concentrations. The results were $0.077 \mathrm{M} \mathrm{F}^{-}$and $0.142 \mathrm{M} \mathrm{PO}_{4}{ }^{3-}$, compared to the theoretical concentrations of $0.070 \mathrm{M}$ and $0.141 \mathrm{M}$.

The first set of solubility tests was dane by dissolving the double sait in stock solutions of (A) $\mathrm{H}_{2} \mathrm{O}$, (B) $1 \mathrm{M} \mathrm{NaOH}$, and (C) $1 \mathrm{M} \mathrm{NaOH} / 2 \mathrm{M} \mathrm{NaNO} / 2 \mathrm{M}$ $\mathrm{NaNO}_{2}$ until the solutions were saturated at approximately $65{ }^{\circ} \mathrm{C}$. (Stock solution $C$ is referred to elsewhere as the $5 \mathrm{M} \mathrm{Na}^{+}$solution.) The solutions were heated to $75{ }^{\circ} \mathrm{C}$ and filtered, and the clear filtrates were transferred to $125 \mathrm{~mL}$ Erlenmeyer flasks (glass) in a $45{ }^{\circ} \mathrm{C}$ shaking water bath. After 24 hours (day 1), the liquid phase from each flask was sampled with a $3 \mathrm{~mL}$ calibrated pipet (calibration done separately for each stock solution at $45{ }^{\circ} \mathrm{C}$ ) and diluted with water to prevent precipitation when the solutions cooled to room temperature. The diluted solutions were analyzed by IC.

The temperature of the shaker bath was lowered to $35{ }^{\circ} \mathrm{C}$ for 24 hours and the sampling was repeated on day 2 . The sampling was repeated at $25^{\circ} \mathrm{C}$ on day $3,15{ }^{2} \mathrm{C}$ on day 4 , and at $25{ }^{\circ} \mathrm{C}$ again on day 9 . 
A new set of stock solutions was prepared by dissolving more of the double salt into fresh stock solutions and filtering as before. This set was sampled for analysis at $75^{\circ} \mathrm{C}$ on day $1,65^{\circ} \mathrm{C}$ on day $2,65^{\circ} \mathrm{C}$ again on day 7 , and $55^{\circ} \mathrm{C}$ on day 13 .

Results of all the analyses are shown in Table 3 and are plotted in Figure 6 . There is some evidence that the solutions react with the glass containers, and the experiment should be repeated in Teflon flasks before the data are considered as accurate as they could be. The concentrations recorded at $65^{\circ} \mathrm{C} /$ day 7 are consistently lower than they are for day 2 at the same temperature, suggesting a slow precipitation of both fluoride and phosphate, but especially fluoride, over the intervening 5 days.

Furthermore, the values recorded at $45{ }^{\circ} \mathrm{C} /$ day 1 tend to be higher in fluoride than the values at $55^{\circ} \mathrm{C} /$ day 13 , leading to the same conciusion, but the trend is not as consistent for fluoride and is absent for phosphate. At lower temperature $\left(25^{\circ} \mathrm{C}\right)$, the slow precipitation appears to have little effect. For both fluoride and phosphate, the values at 3 days and 9 days are in good agreement for the $1 \mathrm{M} \mathrm{NaOH}$ and $5 \mathrm{M} \mathrm{Na}^{+}$solutions. (There appears to be an error for the $\mathrm{H}_{2} \mathrm{O}$ solution at $25^{\circ} \mathrm{C} /$ day 3 sample, perhaps caused by a dilution error.)

What is clear from the data is that the fluoride phosphate double salt would be reasonabiy insoluble under tank waste conditions. It can be assumed that crystals of $\mathrm{Na}_{7} \mathrm{~F}\left(\mathrm{PO}_{2}\right)_{4} \cdot 19 \mathrm{H}_{2} \mathrm{O}$ would 1 ikely be found at room temperature in almost any tank waste that contains both fluoride and phosphate.

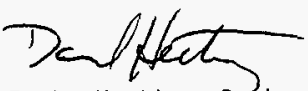

D. L. Herting, Sehior Principal Scientist

Process Chemistry and Statistics

d1s 
Table 3. Solubility of $\mathrm{Na}_{7} \mathrm{~F}\left(\mathrm{PO}_{3}\right) \cdot 19 \mathrm{H}_{3} \mathrm{O}$ Crystals

\begin{tabular}{|c|c|c|c|c|c|c|}
\hline \multicolumn{7}{|c|}{ values in Molarity } \\
\hline Temp, ${ }^{\circ} \mathrm{C}$ & \multicolumn{3}{|c|}{$\mathrm{F}$} & \multicolumn{3}{|c|}{$\mathrm{PO}_{4}^{3-}$} \\
\hline$/ \mathrm{da}^{2}$ & $\mathrm{H}_{2} \mathrm{O}$ & $1 \mathrm{M} \mathrm{NaOH}$ & $5 \mathrm{M}^{1} \mathrm{Na}^{+}$ & $\mathrm{H}_{2} \mathrm{O}$ & $1 \mathrm{M} \mathrm{NaOH}$ & $5 \mathrm{M}^{1} \mathrm{Na}^{+}$ \\
\hline $75 / 1$ & 0.51 & 0.44 & 0.13 & 1.18 & 0.82 & 0.42 \\
\hline $65 / 2$ & 0.40 & 0.33 & 0.081 & 1.02 & 0.63 & 0.30 \\
\hline $65 / 7$ & 0.30 & 0.25 & 0.023 & 0.91 & 0.52 & 0.28 \\
\hline $55 / 13$ & 0.24 & 0.22 & 0.022 & 0.81 & 0.47 & 0.24 \\
\hline $45 / 1$ & 0.30 & 0.15 & 0.042 & 0.54 & 0.28 & 0.090 \\
\hline $35 / 2$ & 0.28 & 0.12 & 0.036 & 0.51 & 0.22 & 0.057 \\
\hline $25 / 3$ & 0.39 & 0.074 & 0.027 & 0.73 & 0.13 & 0.042 \\
\hline $15 / 4$ & 0.26 & 0.11 & 0.045 & 0.49 & 0.19 & 0.057 \\
\hline $25 / 9$ & 0.20 & 0.080 & 0.019 & 0.38 & 0.14 & 0.041 \\
\hline \multicolumn{7}{|c|}{ values in weight percent } \\
\hline Temp, ${ }^{\circ} \mathrm{C}$ & \multicolumn{3}{|c|}{$\mathrm{NaF}$} & \multicolumn{3}{|c|}{$\mathrm{Na}_{3} \mathrm{PO}_{2}$} \\
\hline$/ d a y^{2}$ & $\mathrm{H}_{2} \mathrm{O}$ & $1 \mathrm{M} \mathrm{NaOH}$ & $5 \mathrm{M}^{1} \mathrm{Na}^{+}$ & $\mathrm{H}_{2} \mathrm{O}$ & $1 \mathrm{M} \mathrm{NaOH}$ & $5 \mathrm{M}^{2} \mathrm{Na}^{+}$ \\
\hline $75 / 1$ & 1.82 & 1.62 & 0.45 & 16.6 & 11.7 & 5.6 \\
\hline $65 / 2$ & 1.46 & 1.23 & 0.27 & 14.7 & 9.1 & 4.0 \\
\hline $65 / 7$ & 1.13 & 0.95 & 0.08 & 13.2 & 7.7 & 3.6 \\
\hline $55 / 13$ & 0.89 & 0.83 & 0.07 & 11.8 & 6.8 & 3.1 \\
\hline $45 / 1$ & 1.18 & 0.59 & 0.14 & 8.3 & 4.4 & 1.2 \\
\hline $35 / 2$ & 1.10 & 0.47 & 0.12 & 7.7 & 3.4 & 0.75 \\
\hline $25 / 3$ & 1.55 & 0.29 & 0.09 & 11.3 & 2.0 & 0.56 \\
\hline $15 / 4$ & 1.06 & 0.46 & 0.15 & 7.8 & 3.0 & 0.76 \\
\hline $25 / 9$ & 0.84 & 0.32 & 0.07 & 6.0 & 2.2 & 0.56 \\
\hline
\end{tabular}

$15 \mathrm{M} \mathrm{Na}^{+}=1 \mathrm{M} \mathrm{NaOH} / 2 \mathrm{M} \mathrm{NaNO}_{3} / 2 \mathrm{M} \mathrm{NaNO}_{2}$

2 days after slurry entered shaker bath 
Figure 6. Phosphate Molarity in Solutions Saturated in $\mathrm{Na}_{7} \mathrm{~F}\left(\mathrm{PO}_{4}\right)_{2} \cdot 19 \mathrm{H}_{2} \mathrm{O}$

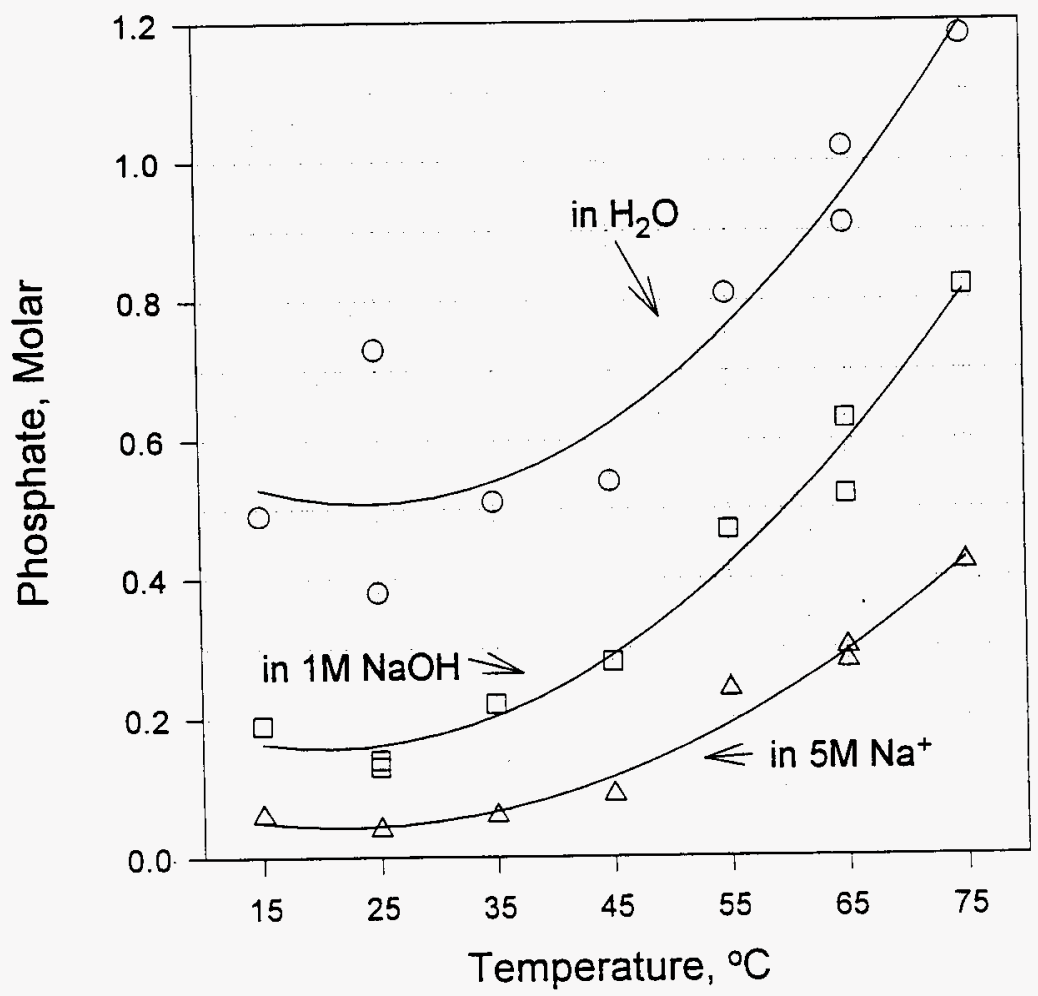


WHC-EP-0915

This page intentionally left blank. 
WHC-EP-0915

\section{DISTRIBUTION}

Number of Copies

OFESITE

2

Argonne National Laboratory

9700 S. Cass Ave.

Argonne, IL 60439

E. P. Horwitz

D. M. Strachan

3

Qak Ridge National Laboratory

P. O. Box 2008

Oak Ridge, TN 37831

J. T. Bell

MS 6223

C. P. McGinnis

J. S. Watson

MS 6227

1

Sandia National Laboratory

P. O. Box 1663

Los Alamos, NM 87545

N. E. Brown

2

Savannah River Technical Center

P. O. Box 616

Aiken, SC 29808

D. T. Hobbs

773-A

M. C. Thompson

1

United States Department of Energy

12800 Middlebrook Road

Trevion II Building

Germantown, MD 20874

K. Gerdes

1

W. W. Schulz

720 Montgomery Boulevard

Albuquerque, NM 87109

Distr-1 


\section{DISTRIBUTION (Continued)}

Number of Copies

\section{OFFSITE}

J. L. Swanson

1318 Cottonwood Drive

Richland, WA 99352

\section{OFFSITE}

INTERNATIONAL

2

Institute of Physical Chemistry

Russian Academy of Sciences

31 Leninsky Prospekt

Moscow, Russia 117915

V. B. Krapukhin

A. K. Pikaev

ONSITE

4

Pacific Northwest National Laboratory

N. G. Colton

K2-40

T. A. Fryberger

K2-20

W. L. Kuhn

K2-21

Hanford Technical Library

SAIC

D. J. Swanberg

H0-50

4

U.S. Department of Energy

Richland Field Office

S. T. Bumum

A2-45

J. A. Frey

K8-50

J. P. Hanson

K8-50

B. A. Mauss

K8-50 
DISTRIBUTION (Continued)

Number of Copies

ONSITE

Westinghouse Hanford Company

W. C. Allan

R3-86

J. N. Appel

G3-21

H. Babad

S7-14

G. S. Barney

T5-12

W. B. Barton

R2-11

J. D. Berger

H6-34

G. T. Berlin

H6-34

D. R. Bratzel

S7-14

K. G. Carothers

R1-56

C. H. Delegard

T6-09

D. W. Edmonson

T6-09

J. S. Garfield

H5- 49

D. W. Hendrickson

L5-31

D. L. Herting (10)

T6-09

J. R. Jewett

T6-09

R. A. Kirkbride

H5-27

M. J. Klem

H5-27

M. J. Kupfer

H5-27

S. L. Lambert

S5-27

G. T. MacLean

H5-61

R. M. Orme

J. C. Person

H5-27

D. A. Reynolds

T6-09

E. J. Slaathaug

R2-11

H5-49

J. P. Sloughter

R2-54

D. J. Washenfelder

H5-27

Central Files

A3-88

Document Processing Center

A3-94 
WHC-EP-0915

This page intentionally left blank.

Distr-4 